\title{
Role of nociceptin/orphanin FQ and nociceptin opioid peptide receptor in depression and antidepressant effects of nociceptin opioid peptide receptor antagonists
}

\author{
Jong Yung Park", Suji Chae", Chang Seop Kim, Yoon Jae Kim, Hyun Joo Yi, Eunjoo Han, Youngshin Joo, Surim Hong, \\ Jae Won Yun, Hyojung Kim, and Kyung Ho Shin*
}

Department of Pharmacology, Korea University College of Medicine, Seoul 02841, Korea

\section{ARTICLE INFO \\ Received June 12, 2019 \\ Revised August 11, 2019 \\ Accepted August 26, 2019 \\ *Correspondence \\ Kyung Ho Shin \\ E-mail: kyungho@korea.ac.kr}

\section{Key Words}

Antidepressive agents

Depression

Neuropeptide

Receptors, drug

\#These authors contributed equally to this work.
ABSTRACT Nociceptin/orphanin FQ (N/OFQ) and its receptor, nociceptin opioid peptide (NOP) receptor, are localized in brain areas implicated in depression including the amygdala, bed nucleus of the stria terminalis, habenula, and monoaminergic nuclei in the brain stem. N/OFQ inhibits neuronal excitability of monoaminergic neurons and monoamine release from their terminals by activation of $\mathrm{G}$ protein-coupled inwardly rectifying $\mathrm{K}^{+}$channels and inhibition of voltage sensitive calcium channels, respectively. Therefore, NOP receptor antagonists have been proposed as a potential antidepressant. Indeed, mounting evidence shows that NOP receptor antagonists have antidepressant-like effects in various preclinical animal models of depression, and recent clinical studies again confirmed the idea that blockade of NOP receptor signaling could provide a novel strategy for the treatment of depression. In this review, we describe the pharmacological effects of N/OFQ in relation to depression and explore the possible mechanism of NOP receptor antagonists as potential antidepressants.

\section{INTRODUCTION}

Depression, characterized by depressed mood, markedly diminished interest or pleasure (anhedonia), disturbances in sleep and appetite, feeling of worthlessness, recurrent thoughts of death or suicide, and other symptoms more than 2 weeks, is among the most disabling mental disorder. Conventional antidepressants are known to enhance serotonergic and/or noradrenergic neurotransmission by blocking the reuptake of serotonin (5-hydroxytryptamine, 5-HT) and/or norepinephrine (NE). Problems of conventional antidepressants treatment through the blockade of reuptake of 5-HT and/or NE are that a subset of depressed patients does not resolve and at least 3-4 weeks are required for the antidepressant effects to become apparent.
In addition to 5-HT and NE, dopamine (DA) is also proposed as a potential target for antidepressant development because anhedonia, one of the core symptoms of depression, is linked to reduced mesolimbic dopaminergic neurotransmission [1]. Accordingly, combination of conventional antidepressants that block the reuptake of 5-HT and/or NE with blockade of DA reuptake would be expected to augment or potentiate the therapeutic efficacy of conventional antidepressants [2]. As a result, it is not surprising that preclinical and clinical researches demonstrate that triplereuptake inhibitors, which block the reuptake of 5-HT, NE, and DA, provide greater efficacy than conventional antidepressants and even exert a faster onset of action [3].

In this regard, N/OFQ is interesting because N/OFQ is related to many biological effects including anxiety and depression (Table (i) \$ This is an Open Access article distributed under the terms of the Creative Commons Attribution Non-Commercial License, which permits unrestricted non-commercial use, distribution, and reproduction in any medium, provided the original work is properly cited. Copyright @ Korean J Physiol Pharmacol, pISSN 1226-4512, eISSN 2093-3827
Author contributions: C.S.K., Y.J.K., H.J.Y, H.J.Y., E.H., Y.J., S.H., J.W.Y., H.K. performed acquisition of data, analysis and/or interpretation of data and drafting the manuscript; J.Y.P., S.C., K.H.S. performed acquisition of data, analysis and/or interpretation of data, drafting the manuscript and revising the manuscript; K.H.S. performed conception and design of study. 


\section{Table 1. Biological effects of N/OFQ}

Antinociceptive effects (in the spinal cord)

Hyperalgesia (in supraspinal area by anti-opioid effects)

Modulation of feeding (orexigenic)

Anxiety

Depression

Modulation of locomotor activity

Learning and memory

Modulation of opioid tolerance

Regulation of body temperature

N/OFQ, nociceptin/orphanin FQ.

1). Among the biological effects, N/OFQ inhibits the release of 5-HT, NE, and DA, thereby reducing monoaminergic neurotransmission, and conversely, NOP receptor antagonists enhance monoaminergic neurotransmission. Consistent with these findings, NOP receptor antagonists show antidepressant-like effects in animal models of depression [4]. Moreover, recent clinical studies demonstrate that LY2940094, NOP receptor antagonist administered per oral, displays antidepressant effects in depressed patients $[5,6]$, providing evidence that blockade of NOP receptor signaling could represent a promising strategy for the treatment of depression. In this review, we describe the pharmacological effects of N/OFQ and explore the underlying mechanism of NOP receptor antagonists as potential antidepressants.

\section{DISCOVERY OF N/OFQ}

Nociceptin opioid peptide (NOP) receptor, formally known as opioid receptor-like 1, KOR3, and OP4, was discovered in human [7], murine [8,9] and porcine [10] brains by selective PCR amplification method based on already identified sequences of opioid receptors. At first NOP receptor was known as an orphan receptor because NOP receptor had been discovered before the identification of its binding ligand, nociceptin/orphanin FQ (N/OFQ) [11]. Later, N/OFQ, a 17-amino acid neuropeptide, was discovered using Chinese hamster ovarian cells that express NOP receptor $[11,12]$. N/OFQ is structurally similar to other endogenous opioid peptides, but the binding affinity of N/OFQ for NOP receptor is 500 -fold and 5000-fold higher than that for mu ( $\mu$ ) and kappa ( $\kappa)$ opioid receptors, and for delta $(\delta)$ opioid receptor, respectively [13]. Although NOP receptor contains similar introns and exons with $\mu, \kappa$, and $\delta$ opioid receptors, N/OFQ shows low specific affinity for other endogenous opioid receptors [14].

\section{N/OFQ AND NOP RECEPTOR DISTRIBUTION}

N/OFQ is highly expressed in neurons and terminals of the cerebral cortex, periaqueductal gray, lateral septum, medial and lateral bed nucleus of the stria terminalis, and medial amygdala, while moderate immunolabeling of N/OFQ in neurons is observed in pyramidal layers of CA1, CA2, CA3, stratum lucidum of CA3, and granule cell layer of dentate gyrus with weak immunolabeling of fibers and terminals [15]. Low to moderate immunolabeling of N/OFQ in neurons and terminals is seen in the hypothalamic paraventricular and ventromedial nuclei, medial preoptic-anterior hypothalamic area, dorsal raphe (DR) and median raphe (MR) as well as in the locus coeruleus (LC). N/OFQ is weakly expressed in scattered neurons of nucleus accumbens core and shell, but immunolabeling of fibers and terminals is higher in the core than in the shell because afferent projections to nucleus accumbens core come from basolateral amygdala (BLA), ventral tegmental area (VTA), and DR in which N/OFQ immunolabeling and mRNA contents are prominent.

NOP receptor mRNA is highly expressed in many brain areas where high N/OFQ immunolabeling is observed in neurons and terminals: cortical layer VI of cerebral cortex, periaqueductal gray, medial and lateral bed nucleus of the stria terminalis, and arcuate nucleus $[15,16]$. Not all brain areas, however, demonstrate corresponding levels of N/OFQ and NOP receptor mRNA expression. For example, high immunolabeling of N/OFQ in neurons, fibers and terminal is found in the central nucleus of the amygdala, but only weak NOP receptor mRNA expression is observed in this nucleus. Conversely, low to moderate immunolabeling of $\mathrm{N} / \mathrm{OFQ}$ in neurons and terminals is observed in the hypothalamic paraventricular and ventromedial nuclei, medial preopticanterior hypothalamic area, DR, and MR as well as in the LC, but these areas show very high NOP receptor mRNA expression.

In addition, although NOP receptor mRNA expression and specific N/OFQ binding, as demonstrated by ${ }^{125} \mathrm{I}-\left[{ }^{14} \mathrm{Tyr}\right]-\mathrm{OFQ}$ binding, are distributed similarly in most brain areas, there are some brain areas that show high NOP receptor mRNA expression but no N/OFQ binding and vice versa [16]. High NOP receptor mRNA expression but no detectable N/OFQ binding is found in limbic brain areas such as basomedial amygdala, pyramidal layer of CA3, granule cell layer of the dentate gyrus, posterolateral and medial posteromedial divisions of bed nucleus of the stria terminalis, and other brain areas [16]. Conversely, brain areas with weak NOP receptor mRNA expression but high N/OFQ binding are located in the olfactory bulb, molecular layer of dentate gyrus, suprachiasmatic nucleus of hypothalamus, and multiple thalamic nuclei, including anteroventral, laterodorsal, paracentral, and ventromedial nuclei. The discrepancy between NOP receptor mRNA expression and N/OFQ binding can be explained in two ways. One plausible explanation is that NOP receptor is produced in various neuronal cell bodies and transported to the distal sites that do not express NOP receptor mRNA [7,16]. Similar discrepancy in the distribution of receptor mRNA and its agonist binding site was observed in the opioid system [17]. Alternatively, high NOP receptor mRNA is transcribed within the neuronal cell bodies but NOP receptor mRNA could not be translated in paral- 
lel [16], thus preventing agonist binding to the NOP receptor.

\section{N/OFQ AND NOP RECEPTOR SIGNALING}

NOP receptor, a member of G protein-coupled receptor (GPCR) superfamily, is linked to pertussis toxin (PTX)-sensitive and insensitive Gi proteins $\left(G \alpha_{i}, G \alpha_{o}\right.$ and $G \alpha_{2}$, respectively) or PTXinsensitive $G q$ proteins $\left(G_{\alpha 14} / G_{\alpha 16}\right)$ [18]. Different forms of $\alpha$ subunits of $\mathrm{Gi}\left(\mathrm{G}_{\mathrm{\alpha i}}, \mathrm{G}_{\alpha \mathrm{o}}\right.$, and $\left.\mathrm{G}_{\alpha z}\right)$ inhibit adenylyl cyclase activity thereby suppressing cAMP formation and protein kinase A (PKA) activation, whereas $\alpha$ subunits of $G q\left(G_{\alpha 14} / G_{\alpha 16}\right)$ stimulate phospholipase $\mathrm{C} \beta$ and subsequent protein kinase $\mathrm{C}$ (PKC) activation.

NOP receptor activates different types of mitogen-activated protein kinase (MAPK) including extracellular-signal regulated kinase 1/2 (Erk $\left.{ }_{1 / 2}\right)$, p38 MAPK, and c-JunN-terminal kinase (JNK) [19]. NOP receptor-induced phosphorylation and activation of Erk $_{1 / 2}$ involves both PKC-dependent and PKC-independent pathways, because PKC inhibitors attenuate, but not completely abolish NOP receptor-induced $\mathrm{Erk}_{1 / 2}$ activation [18]. In PKC-independent pathways, $\beta \gamma$ subunits released from Gi or Gq after NOP receptor activation trigger Ras-Raf-MAPK kinase (MEK) and $\mathrm{Erk}_{1 / 2}$ cascade. The $\beta \gamma$ subunits released from Gi or Gq after NOP receptor activation also increase phosphorylation of p38 MAPK through Ras [20]. Both PKA and PKC are involved in NOP receptor-mediated phosphorylation and activation of $\mathrm{p} 38$ MAPK and $\mathrm{Erk}_{1 / 2}$ in a different manner because PKA is partially required for p38 MAPK phosphorylation, whereas PKC is required for Erk 1/2 $_{12}$ phosphorylation.

In addition to regulation of second messenger, GPCR coupled to $G_{\alpha \mathrm{i}}$ and $G_{\alpha o}$ is known to regulate ion channels primarily through G $\beta \gamma$ subunits. Hence, it is not surprising that NOP receptor activation not only inhibits voltage-dependent calcium channels, but also stimulates $G$ protein-coupled inwardly rectifying $\mathrm{K}^{+}$channels (GIRK). NOP receptor activation inhibits L-, N-, and P/Q-type voltage sensitive calcium channels [21]. Among the calcium channels, presynaptic inhibition of $\mathrm{N}$ - and P/Q-type voltage sensitive calcium channels by NOP receptor activation suppresses the release of NE, DA, 5-HT, acetylcholine, glutamate, and gamma-aminobutyric acid (GABA) [19]. Postsynaptic activation of GIRK by NOP receptor produces postsynaptic neuronal hyperpolarization, thereby suppressing neuronal excitability.

\section{ELECTROPHYSIOLOGICAL EFFECTS OF N/OFQ}

$\mathrm{N} / \mathrm{OFQ}$ reduces neurotransmitter release in presynaptic nerve terminals and inhibits neuronal excitability in postsynaptic neurons. Many of N/OFQ effects are mediated by presynaptic and postsynaptic ion channels, most of which are different types of potassium and calcium channels.

\section{Voltage sensitive M-type $\mathrm{K}^{+}$channels}

Neuronal M-type $\mathrm{K}^{+}$channels partially open at resting membrane potential and become more and more open as depolarization proceeds in a non-inactivating manner. As the process of opening and closing $\mathrm{M}$-type $\mathrm{K}^{+}$channels is very slow, blockade of depolarization could occur during repetitive action potential firings, thus regulating neuronal excitability. N/OFQ activates M-type $\mathrm{K}^{+}$channels in the hippocampus (Fig. 1) and suppresses spontaneous bursting of hippocampal CA3 neurons as well as evoked EPSC induced by stimulation of either mossy fiber or associational/commissural (A/C) fiber [22]. Thus it is probable that the antiepileptic effect of N/OFQ appears to be mediated by activation of M-type $\mathrm{K}^{+}$channels, but the suppressive effect of N/OFQ on spontaenous bursting of hippocampal CA3 neurons is not reversed by linopirdine, $\mathrm{M}$-type $\mathrm{K}^{+}$channels antagonist. This result suggests that antiepileptic effect of N/OFQ may not be attributable to the activation of M-type $\mathrm{K}^{+}$channels in the hippocampus.

\section{Voltage sensitive transient outward A-type $\mathrm{K}^{+}$channels}

Voltage sensitive transient outward A-type $\mathrm{K}^{+}$channels are rapidly activated and then inactivated with a more extended time course resembling voltage-dependent $\mathrm{Na}^{+}$channels [23]. Voltage sensitive transient outward A-type $\mathrm{K}^{+}$channels are largely inactivated at membrane potential more positive than $-45 \mathrm{mV}$ and are activated transiently during depolarization following afterhyperpolarization. The activation of voltage sensitive transient outward A-type $\mathrm{K}^{+}$channels dampens the firing frequency in repetitive firing or slows the onset of action potential under the condition of sustained stimulus. N/OFQ inhibits voltage sensitive transient outward A-type $\mathrm{K}^{+}$channels in neurons of diagonal band of Broca [24], but the functional role of this inhibition is not clear at present (Fig. 1).

\section{Delayed rectifier $\mathrm{K}^{+}$channels}

Delayed rectifier $\mathrm{K}^{+}$channels show a prolonged $\mathrm{K}^{+}$efflux with delayed activation after depolarization and a slow inactivation over seconds, thereby facilitating repolarization. N/OFQ is found to inhibit delayed rectifier $\mathrm{K}^{+}$channels in neurons of diagonal band of Broca [24] (Fig. 1). Similar dose-dependent inhibition of delayed rectifier $\mathrm{K}^{+}$channels by $\mathrm{N} / \mathrm{OFQ}$ is observed in rat parietal cortical neurons [25]. This inhibition is mediated by Erk1/2 and CaMKII because U0126, Erk1/2 inhibitor, and KN-62, CaMKII inhibitor, block the N/OFQ-induced inhibition of delayed rectifier $\mathrm{K}^{+}$channels. As blockade of delayed rectifier $\mathrm{K}^{+}$channels increases the duration of action potential by the prolongation of repolarization [26], N/OFQ could suppress neuronal excitability. 


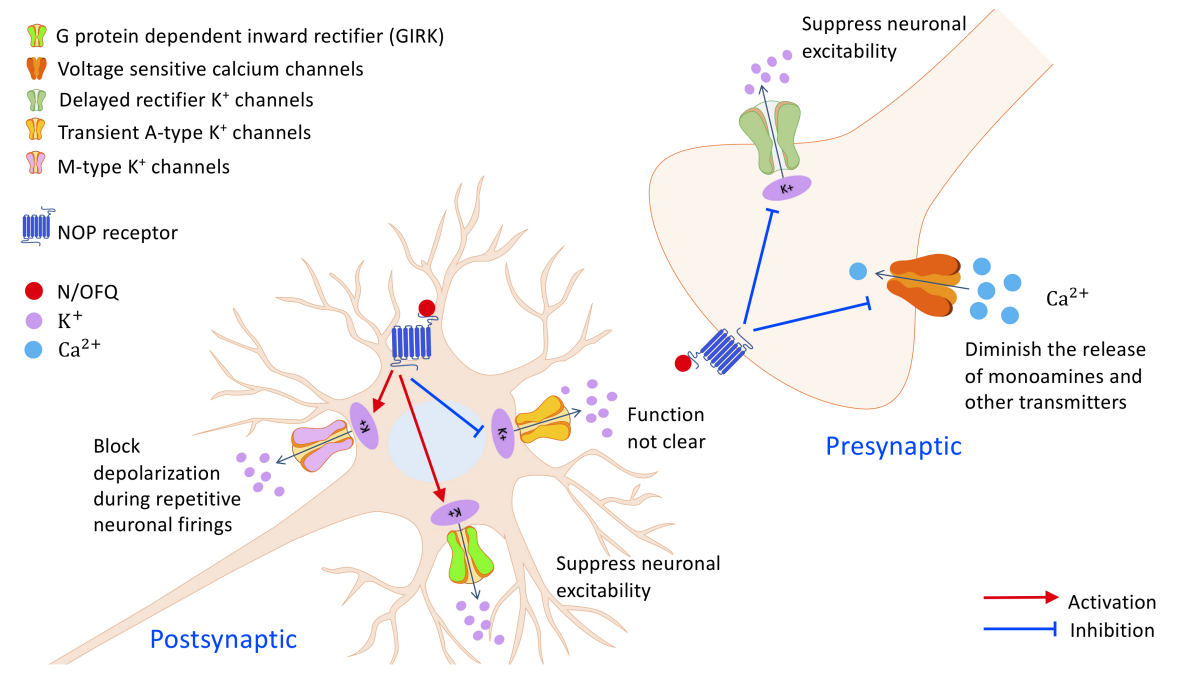

Fig. 1. Electrophysiological effects of nociceptin/orphanin FQ (N/OFQ) on ion channels in neuronal cell body and axon terminals. Nociceptin opioid peptide (NOP) receptor activation by N/OFQ stimulates G protein-coupled inwardly rectifying $\mathrm{K}^{+}$channels (GIRK) and voltage sensitive M-type $\mathrm{K}^{+}$channels, but inhibits voltage sensitive transient outward A-type $\mathrm{K}^{+}$channels in neuronal cell body. Presynaptic NOP receptor activation in axon terminals inhibits voltage sensitive calcium channels and delayed rectifier $\mathrm{K}^{+}$channels. N/OFQ inhibits neuronal excitability and neurotransmitter release from axon terminals by activation of GIRK and inhibition of voltage sensitive calcium channels, respectively. For example, release of norepinephrine, dopamine, 5-hydroxytryptamine (serotonin), acetylcholine, and glutamate from their terminals are known to be inhibited by N/OFQ. This scheme is modified using Motifolio Scientific Illustration Toolkits for Presentations and Publications (www.motifolio.com).

\section{G-protein coupled inwardly rectifying $\mathrm{K}^{+}$channels}

Inwardly rectifying $\mathrm{K}^{+}$channels open when the membrane potential hyperpolarizes more than potassium equilibrium potential $\left(\mathrm{E}_{\mathrm{k}}\right)$ and close as the membrane potential depolarizes. Accordingly, outward flow of $\mathrm{K}^{+}$is more prominent as membrane potential is more positive to the $\mathrm{E}_{\mathrm{k}}$. Even though the amount of outward flow of $\mathrm{K}^{+}$is not large, the activation of inwardly rectifying $\mathrm{K}^{+}$ channels below threshold helps the stabilization of membrane potential and dampens the possibility of depolarization. Among the seven subunits of inwardly rectifying $\mathrm{K}^{+}$channels (Kir1-7), Kir3 subfamily is known as GIRK, because activation of neurotransmitter receptors coupled to Gi/o liberates $\beta \gamma$ subunits, leading to activation of GIRK.

$\mathrm{N} / \mathrm{OFQ}$ is known to activate inwardly rectifying $\mathrm{K}^{+}$channels in neurons of DR [27] and LC [28]. Outward $\mathrm{K}^{+}$currents through inwardly rectifying $\mathrm{K}^{+}$channels have been observed in many brain areas including ventromedial hypothalamic nucleus [29], arcuate nucleus [29,30], supraoptic nucleus [31], and ventrolateral PAG [32]. The involvement of G-proteins for inwardly rectifying $\mathrm{K}^{+}$ channels was first suggested by Ikeda et al. [33] because addition of GTP $\gamma$ S, nonhydrolyzable GTP that can induce irreversible dissociation of $\beta \gamma$ subunits from $\alpha$ subunit and activates $\beta \gamma$ subunits of Gi/o, to pipette solution of whole cell patch clamp activates inwardly rectifying $\mathrm{K}^{+}$channels in mouse hippocampal CA3 pyramidal cells (Fig. 1). This postulation was further complemented by findings that N/OFQ-induced activation of GIRK is blocked by incubation of brain slice with either GDP- $\beta$-S, a nonhydrolyzable GDP analog that competitively inhibits G-protein mediated actions or pertussis toxin, which catalyzes the ADP-ribosylation of $\alpha$ subunits leading to irreversible inactivation of Gai/o [34].

The role of GIRK for hyperpolarization effect of N/OFQ is further supported by findings that N/OFQ-induced outward potassium currents in the arcuate nucleus and ventromedial nucleus of the hypothalamus are suppressed by tertiapin [35] and SKH23390 [36], both of which are known as selective GIRK inhibitors. Outward $\mathrm{K}^{+}$currents through GIRK have been demonstrated in many brain areas including ventromedial nucleus of hypothalamic nucleus [36], arcuate nucleus [37,38], perifornical and lateral areas of tuberal hypothalamus [39], hippocampal pyramidal neurons [33], lateral and central amygdala [34], thalamic reticular nucleus (NRT), and ventrobasal complex [40]. GIRK activation by N/OFQ in these brain areas hyperpolarizes neurons and thus inhibits neuronal excitability.

\section{Calcium activated big conductance $\mathrm{K}^{+}(\mathrm{BK})$ channels}

BK channels are large conductance calcium- and voltagedependent channels. BK channels open in response to a depolarization-induced calcium influx and accelerate the repolarization of action potential. N/OFQ suppresses N- and L-type calcium channels, which in turn, leads to the inhibition of BK channels in neurons in the diagonal band of Broca neurons [24]. The inhibition of BK channels by N/OFQ in conjunction with the blockade of L-type and N-type calcium channels results in the inhibition of acetylcholine release and neuronal excitability in the diagonal band of Broca. 


\section{Voltage sensitive calcium channels}

The finding that N/OFQ inhibits N-type calcium channels was first demonstrated in SH-SY5Y human neuroblastoma cell line [41]. This effect seems to be mediated by Gi/o because the $\mathrm{N} / \mathrm{OFQ}$-induced suppression of $\mathrm{N}$-type calcium channels is no longer evident after the treatment of pertussis toxin. Later, a more detailed study revealed that N/OFQ inhibits not only N-type calcium channels but also other high voltage activated (HVA) calcium channels like L-type and P/Q-type calcium channels in the hippocampal CA3 and CA1 neurons [21]. The inhibition of HVA calcium channels by N/OFQ is recovered over time, but the addition of GTP $\gamma$ S, thereby activating $\beta \gamma$ subunits of $\mathrm{Gi} / \mathrm{o}$, to the patch pipette sustains the inhibition of HVA calcium channels by N/OFQ. Moreover, a prepulse depolarization, which dissociates $\beta \gamma$ subunits of $\mathrm{Gi} / \mathrm{o}$ from the calcium channels, reduces the inhibition of HVA calcium channels by N/OFQ [42]. These findings provide additional support to the idea that $\beta \gamma$ subunits of $\mathrm{Gi} /$ o protein may mediate the suppressive effect of N/OFQ on HVA calcium channels [43].

The inhibition of HVA calcium channels by N/OFQ has been demonstrated in the LC neurons [41] and hippocampal pyramidal neurons [21,44] (Fig. 1). The inhibition of HVA calcium channels in the LC seems to be involved with the inhibition of NE release. Interestingly, the inhibition of HVA calcium channels by $\mathrm{N} / \mathrm{OFQ}$ is largely found in pain-related areas including rostral ventromedial medulla [42], periaqueductal gray [45], trigeminal ganglia [46], and dorsal root ganglia [47,48].

Prolonged exposure to high dose of N/OFQ seems to desensitize HVA calcium channels as the N/OFQ exposure in the dorsal root ganglia rapidly attenuates the inhibition of HVA calcium channels [48]. The desensitization of HVA calcium channels tends to be mostly mediated by N-type calcium channels through internalization of NOP receptor [49]. However, it is under debate whether desensitization of N-type calcium channels by high dose of N/OFQ is caused by internalization of NOP receptor alone [48] or co-internalization of NOP receptor along with N-type calcium channels [47], because G $\beta \gamma$ subunits of NOP receptor are found to interact directly with $\alpha 1$ subunits of $\mathrm{N}$-type calcium channels [47].

\section{N/OFQ AND NE}

N/OFQ and NOP receptor are localized in the LC and its projection areas such as BLA, prefrontal cortex (PFC), and hippocampus $[15,16]$. Intracellular recordings in the brain slices demonstrate that N/OFQ activates inwardly rectifying potassium channels in the LC neurons [28], thereby presumably inhibiting activity of noradrenergic LC neurons [50]. The activation of inwardly rectifying potassium channels in the LC is blocked by pretreatment with UFP-101, NOP receptor antagonist [50], suggesting that this effect is mediated by NOP receptor.
$\mathrm{N} / \mathrm{OFQ}$ inhibits NE release by acting on NOP receptor in the LC and axon terminals in the BLA and PFC, but the NE release in the BLA and PFC following NOP receptor activation is regulated in a rather different manner (Fig. 2). For example, injection of $\mathrm{N} /$ OFQ into the BLA significantly reduces NE release in the BLA [51], whereas intraperitoneal injection of NOP receptor antagonist J-113397 significantly increases NE release in the BLA. Although the site of action of J-113397 in brain is obscure, as J-113397 is intraperitoneally injected, NOP receptor in the BLA seems to be involved with tonic inhibition of NE release because simultaneous infusion of N/OFQ into the BLA blocks the increase in NE release induced by J-113397. Similarly, the infusion of N/OFQ into the PFC [52] or the injection of $\mathrm{NCNH}_{2}$, NOP receptor agonist, into the LC [53] significantly decreases NE release in the PFC of

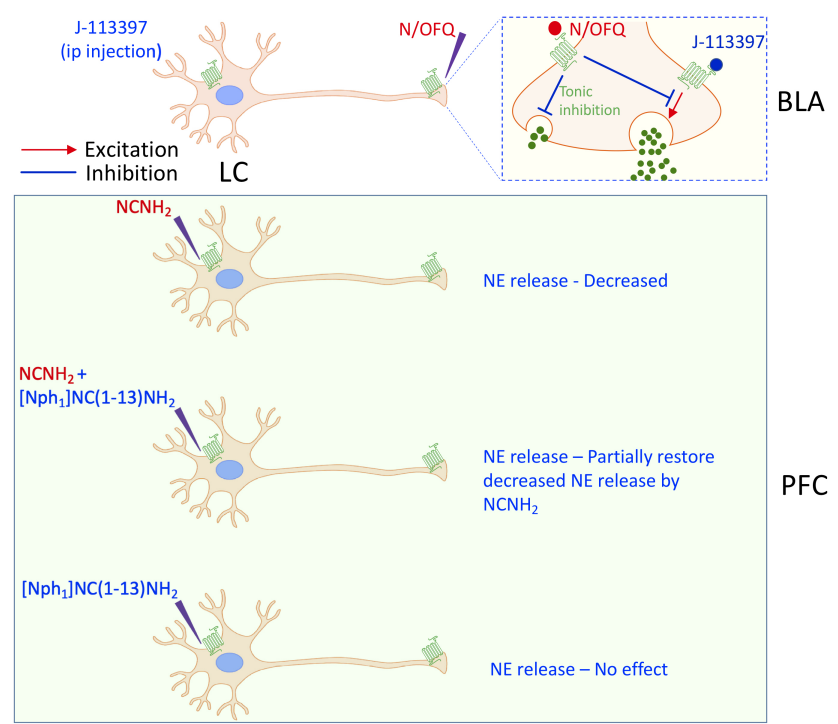

Fig. 2. Inhibitory effects of nociceptin/orphanin FQ (N/OFQ) on noradrenergic neurotransmission. Nociceptin opioid peptide (NOP) receptor is distributed on norepinephrine (NE) neurons in the locus coeruleus $(\mathrm{LC})$ and their terminals in the basolateral amygdala (BLA) and prefrontal cortex (PFC). N/OFQ inhibits activity of noradrenergic $\mathrm{LC}$ neurons and leads to diminish NE release in the BLA and PFC. There is also evidence that N/OFQ reduces NE release by acting on NOP receptor at axon terminals in the BLA and PFC, but the NE release in the $\mathrm{BLA}$ and PFC following NOP receptor activation is regulated in a rather different manner. Intraperitoneal injection of NOP receptor antagonist $\mathrm{J}-113397$ increases NE release and the simultaneous infusion of N/OFQ into the BLA blocks the effects of J-113397 indicating that NOP receptor in the BLA appears to exert tonic inhibitory effects on NE release. On the contrary, local injection of NOP receptor agonist $\mathrm{NCNH}_{2}$ into the $\mathrm{LC}$ decreases NE release in the PFC and this effect is partially restored by co-administration of NOP receptor antagonist [Nphe $\left.{ }^{1}\right] \mathrm{NC}(1-13) \mathrm{NH}_{2}$ and $\mathrm{NCNH}_{2}$ into the LC. Interestingly, injection of [Nphe $\left.{ }^{1}\right] \mathrm{NC}(1-13) \mathrm{NH}_{2}$ into the $L C$ is without effect on NE release in the PFC per se. Thus, NOP in the LC seems not to exert tonic inhibition of NE release in the PFC. In vitro studies using brain slice and synaptosome demonstrate that $\mathrm{N}$ / OFQ also diminishes the release of NE in the frontal cortex. This scheme is modified using Motifolio Scientific Illustration Toolkits for Presentations and Publications (www.motifolio.com). 
freely moving rats. Interestingly, injection of [Nphe $\left.{ }^{1}\right] \mathrm{NC}(1-13)$ $\mathrm{NH}_{2}$, NOP receptor antagonist, alone into the LC has no effect on the NE release in the PFC, but simultaneous injection of [Nphe ${ }^{1} \mathrm{NC}(1-13) \mathrm{NH}_{2}$ and $\mathrm{NCNH}_{2}$ into the LC partially prevents the decrease in NE release in the PFC observed after injection of $\mathrm{NCNH}_{2}$ into the LC. This result indicates that NOP receptor in the LC may not exert tonic inhibitory effect on NE release in the PFC.

As with in vivo experiments, in vitro studies show that N/OFQ inhibits the release of $\left[{ }^{3} \mathrm{H}\right]-\mathrm{NE}$ in the cerebrocortical slice and synaptosome obtained from rat fronto-temporal cortex evoked by either electrical stimulation or high calcium concentration [54]. This inhibition is reversed by NOP receptor antagonist [Nphe ${ }^{1}$ ] $\mathrm{NC}(1-13) \mathrm{NH}_{2}$, while perfusion of $\left[\mathrm{Nphe}^{1}\right] \mathrm{NC}(1-13) \mathrm{NH}_{2}$ alone under the condition of electrical stimulation is without effect on NE release in the cerebrocortical slice. Similar inhibition of NE release by N/OFQ and its reversal by NOP receptor antagonists such as [Nphe $\left.{ }^{1}\right] \mathrm{NC}(1-13) \mathrm{NH}_{2}$, UFP-101, J-113397, and JTC-801 is observed in rat cerebrocortical slice from parieto-occipital cortex [55] and in synaptosomes from fronto-parietal cortex [56]. The inhibitory effect of N/OFQ on NE release induced by high potassium in cerebrocortical slices from rat and mouse is still maintained even when impulse propagation along the axon is blocked by tetrodotoxin $[55,57,58]$, suggesting that N/OFQ inhibits NE release in the PFC through the activation of NOP receptor on axon terminals in the frontal cortex. Together, those findings suggest that NOP receptor in the BLA appears to be involved in tonic inhibitory effects on NE release, but tonic inhibitory role of NOP receptor in the PFC on NE release remains to be determined.

\section{N/OFQ AND DA}

N/OFQ and NOP receptor are present in the VTA, substantia nigra and their terminals $[15,16,59,60]$. N/OFQ is largely located on GABAergic neurons in the VTA, as $50 \%-60 \%$ of N/OFQpositive neurons express glutamic acid decarboxylase 65 and 67 [60], markers for GABAergic neurons. In contrast, NOP receptor is mostly found in dopaminergic neurons in the VTA [61] because approximately $50 \%$ of tyrosine hydroxylase mRNA positive neurons express NOP receptor mRNA expression and up to $75 \%$ of NOP-positive neurons express TH mRNA [60]. Moreover, the injection of 6-hydroxydopamine (6-OHDA), a neurotoxin that selectively damages catecholaminergic neurons, into medial forebrain bundle to lesion dopaminergic neurons in VTA and substantia nigra, reduces NOP receptor mRNA to $\sim 20 \%$ of controls in the VTA, suggesting that NOP receptor is located on dopaminergic neurons in the VTA.

N/OFQ inhibits DA synthesis and release in the nucleus accumbens. For example, in synaptosomes obtained from rat accumbens, N/OFQ inhibits DA synthesis through suppressing the phosphorylation of $\mathrm{Ser}^{40}$ tyrosine hydroxylase, which is com- pletely blocked by Compound B, NOP receptor antagonist [62]. N/OFQ also inhibits the increase in DA synthesis induced by forskolin, a direct activator of adenylyl cyclase, but not by dibutyryl cAMP, which is known to bypass the adenylyl cyclase system. This result demonstrates that N/OFQ inhibits adenylyl cyclase through presynaptic NOP receptor on DA nerve terminals in the nucleus accumbens, which, in turn leads to suppress the phosphorylation of $\mathrm{Ser}^{40}$ tyrosine hydroxylase and DA synthesis.

In addition to the inhibition of DA synthesis, N/OFQ inhibits $\mathrm{DA}$ release in the nucleus accumbens. Intracerebroventricular (icv) administration of N/OFQ in rats reduces DA release in the nucleus accumbens in a dose dependent manner $[63,64]$. Similar findings are observed in mice in which icv injection of N/OFQ suppresses DA release in the nucleus accumbens [65]. Although it is unclear which brain areas are involved with inhibitory effect on DA release in the nucleus accumbens, NOP receptor activation in the VTA is likely to play a more important role than that in the nucleus accumbens because, whereas direct retrodialysis infusion of N/OFQ into the VTA reduces DA release in rat nucleus accumbens [64], this effect is not observed with retrodialysis infusion of N/OFQ into the nucleus accumbens [66]. Moreover, while direct depolarization of the DA nerve terminals by high extracellular $\mathrm{K}^{+}$increases DA release in primary culture of rat midbrain DA neurons containing soma and terminals, N/OFQ has no effect on high extracellular $\mathrm{K}^{+}$-induced DA release [67]. As high extracellular $\mathrm{K}^{+}$directly depolarizes nerve terminals and induces $\mathrm{Ca}^{2+}$ influx, these results suggest that the primary mechanism mediating the effects of N/OFQ on basal DA release in the nucleus accumbens involves regulation of the firing rate of the DA neurons in the VTA, but does not involves NOP receptor on DA nerve terminals. On the contrary, retrodialysis infusion of N/OFQ into the nucleus accumbens of freely moving rats, being ineffective in DA release per se, significantly suppresses DA release induced by intraperitoneal injection of cocaine. These results suggest that NOP receptor on DA nerve terminals appears to be involved with phasic inhibition of DA release in the nucleus accumbens.

The inhibition by N/OFQ of DA release in the nucleus accumbens is induced directly by suppressing dopaminergic neurons in the VTA and/or indirectly by increasing GABA release in the VTA (Fig. 3) because retrodialysis infusion of N/OFQ into the VTA increases GABA release in this area [64]. Moreover, intraVTA injection of N/OFQ reduces DA release in the nucleus accumbens and this effect is no longer apparent by simultaneous intra-VTA injection of bicuculline and N/OFQ. However, it should be noted that N/OFQ in fact does not increase GABA release in primary culture of rat midbrain DA neurons, but rather reduces GABA release [67]. In line with this observation, N/OFQ hyperpolarizes both GABAergic- and dopaminergic-neurons of the VTA in brain slice [68], thereby suppressing GABAergic neurotransmission in the VTA.

The inconsistent results from in vitro and in vivo experiments could be explained by an interaction between GABAergic and 


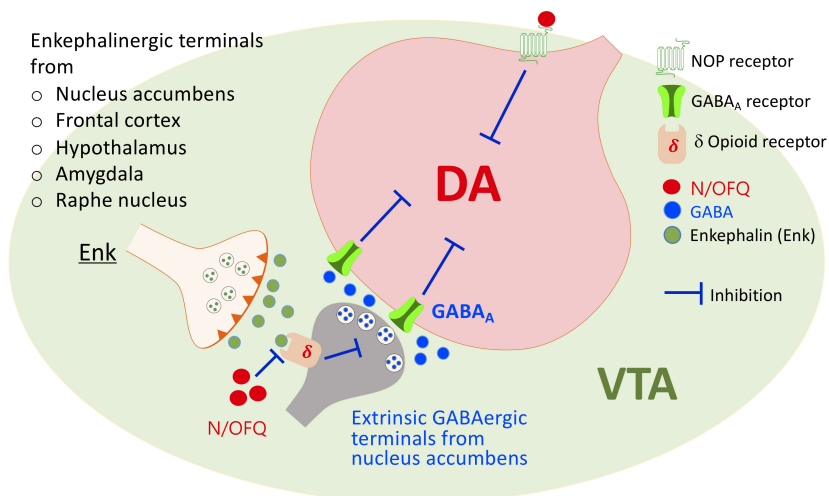

Fig. 3. Inhibition of dopamine (DA) release by nociceptin/orphanin FQ (N/OFQ) in the ventral tegmental area (VTA). N/OFQ inhibits DA release in the VTA and its terminals via both direct and indirect hyperpolarization of DA neurons. N/OFQ activates NOP receptors localized on DA neurons directly followed by a decrease in its neuronal activity. GABAergic terminals in the VTA are largely apposed by enkephalinergic nerve terminals and release of GABA is often presynaptically inhibited by enkephalin. N/OFQ is known to block released enkephalin (Enk) via anti-opioid effects, and thus reduced enkephalinergic tone could increase GABA release in the VTA. Therefore, DA neuronal activity in the VTA is suppressed by direct inhibitory effect of N/OFQ along with enhanced GABAergic neurotransmission indirectly. $\delta$, delta-opioid receptors; $\mathrm{GABA}_{\mathrm{A}^{\prime}} \mathrm{Y}$-aminobutyric acid A receptors. This scheme is modified using Motifolio Scientific Illustration Toolkits for Presentations and Publications (www.motifolio.com).

enkephalinergic nerve terminals in the VTA [69]. Cell bodies and dendrites of DA neurons in the VTA are in contact with GABAergic and enkephalinergic terminals. GABAergic terminals in the VTA are derived from either local interneurons or GABAergic projection neurons from the nucleus accumbens [70], whereas enkephalinergic terminals originate from the nucleus accumbens, frontal cortex, hypothalamus, amygdala, raphe nucleus, and intrinsic VTA neurons [71]. Based on the findings that GABAergic terminals are closely apposed by enkephalinergic terminals [69] and enkephalin often presynaptically inhibits the release of neurotransmitters including GABA [72,73], enkephalin appears to exert tonic inhibition onto GABAergic neurons. Considering that N/OFQ blocks the action of released enkephalin through anti-opioid effects [74], and enkephalin tends to inhibit GABA release $[72,73]$, it is feasible that N/OFQ would increase GABA release in the VTA in vivo. Moreover, there is reciprocal connections between VTA and nucleus accumbens in that dopaminergic terminals from the VTA predominantly forms inhibitory synapse on GABAergic neurons in the nucleus accumbens [75], and GABAergic and enkephalinergic neurons in the nucleus accumbens sends projections to the dopaminergic neurons in the VTA $[69,70]$. If N/OFQ inhibits dopaminergic neurons in the VTA, N/OFQ is likely to increase GABA release in the VTA in vivo through the disinhibition of GABAergic projection neurons from the nucleus accumbens to the VTA [68]. However, under the condition of in vitro brain slice where the reciprocal connections between VTA and nucleus accumbens are removed, GABAergic neurotransmission in the VTA would be suppressed as the result of direct hyperpolarization and subsequent inhibition of local GABAergic interneurons by $\mathrm{N} / \mathrm{OFQ}$.

\section{N/OFQ AND 5-HT}

$\mathrm{N} / \mathrm{OFQ}$ and NOP receptor are found in the DR and MR and their terminals in the frontal cortex, medial and lateral septum, hypothalamus, hippocampus, striatum, and nucleus accumbens $[15,16,76]$. Although it is not clear whether N/OFQ is present in 5 -HT neurons in the DR, NOP receptor in the DR appears to be located on 5-HT neurons since the injection of 5,7-dihydroxytryptamine, neurotoxin which preferentially destroys 5 -HT neurons, into rat DR significantly reduces 5 -HT content in the DR by $70 \%$ with similar magnitude of decrease in $\left.{ }^{3} \mathrm{H}\right]$ nociceptin binding and $\left[{ }^{3} \mathrm{H}\right]$ citalopram binding [77]. This result suggests that NOP receptor is largely distributed on 5-HT neurons in the DR.

$\mathrm{N} / \mathrm{OFQ}$ reduces 5-HT release in the DR and their terminals such as cerebral cortex and nucleus accumbens by regulating the firing rate of DR neurons and acting on 5-HT terminals through NOP receptor. N/OFQ increases inwardly rectifying $\mathrm{K}^{+}$conductance in DR neurons [33,42], which in turn leads to reduced firing rate of 5-HT neurons in the DR. Consistent with this finding, single unit extracellular recording in DR slices demonstrates that $\mathrm{N} / \mathrm{OFQ}$ reduces the firing rate of putative 5-HT neurons in the DR [78]. UFP-101, inactive on its own, shifts the N/OFQ concentration-response curve to the right in DR slices, suggesting that N/OFQ inhibits the firing rate of putative 5-HT neurons through NOP receptor. Similarly, N/OFQ inhibits electrically stimulated $\left.{ }^{3} \mathrm{H}\right] 5-\mathrm{HT}$ release in DR slices, which is prevented by UFP-101 although UFP-101 per se has no effect on the electrically stimulated $\left[{ }^{3} \mathrm{H}\right] 5-\mathrm{HT}$ release [79]. In line with in vitro studies, an in vivo microdialysis study shows that $\mathrm{N} / \mathrm{OFQ}$ infusion into the DR decreases extracellular levels of 5-HT in rats, which is significantly attenuated by prior infusion of [ $\left.\mathrm{Nphe}^{1}\right] \mathrm{NC}(1-13) \mathrm{NH}_{2}$, NOP receptor antagonist, into DR [80]. In contrast to these studies, N/OFQ infusion into the DR increases extracellular 5-HT, an effect that is blocked by concomitant infusion of UFP-101, while UFP-101 alone is devoid of any intrinsic effect [81]. Although the reason for this discrepancy is not clear, it seems likely that N/OFQ may exert biphasic effect on 5-HT neurons in the DR: low doses of N/ OFQ $(1-10 \mu \mathrm{M})$ stimulate 5-HT neurons via NOP receptor on GABA neurons through disinhibition [81], but high doses of N/ OFQ (100-300 $\mu \mathrm{M}$ ) suppress 5-HT neurons in the DR [80] (Fig. 4). In addition, several in vitro [78,79] and in vivo [81] studies using UFP-101 suggests that there is no tonic inhibition of endogenous N/OFQ on 5-HT release in the DR. However, there is a contradictory report that local infusion of [ $\left.\mathrm{Nphe}^{1}\right] \mathrm{NC}(1-13) \mathrm{NH}_{2}$ alone into the DR increases 5-HT release in the DR, suggesting a tonic inhibition of endogenous N/OFQ on 5-HT release in the DR [80]. 

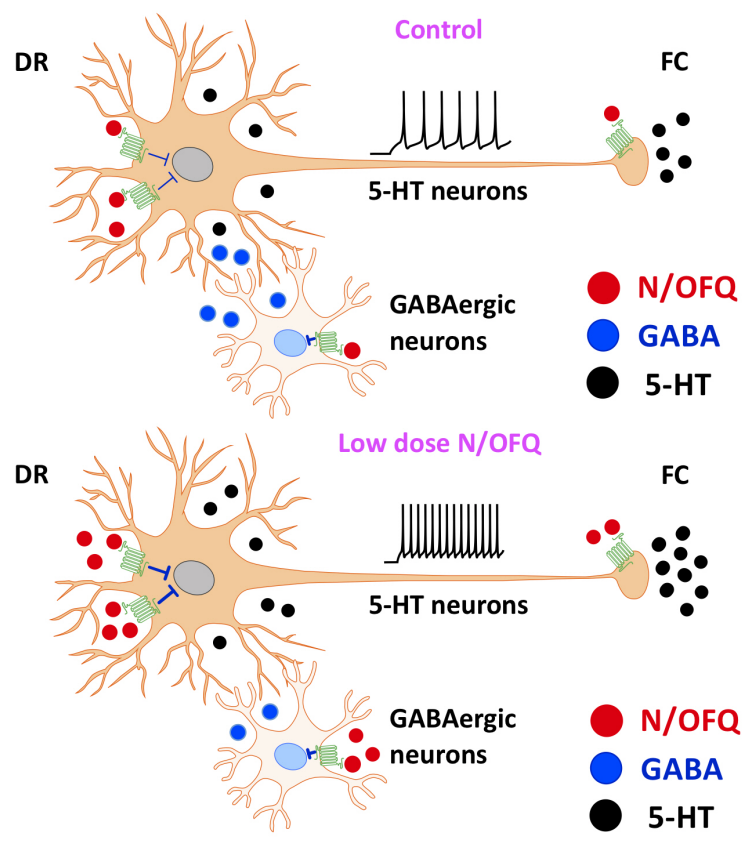

Stimulate 5-HT neurons via NOP receptor on GABA neurons through disinhibition in the DR

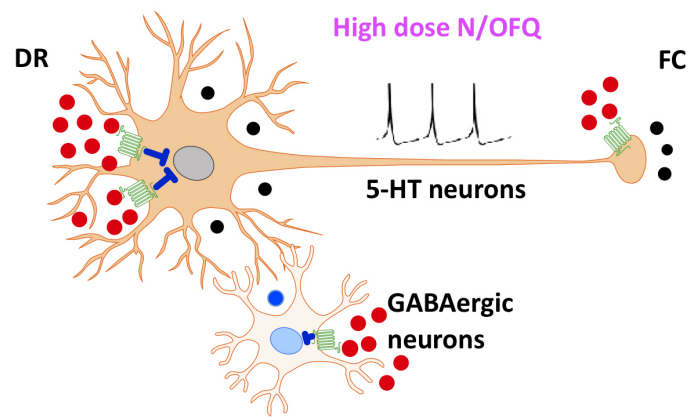

Direct suppression of 5-HT neurons through NOP receptor in the $D R$

Fig. 4. Regulation of 5-hydroxytryptamine (5-HT) release by nociceptin/orphanin FQ (N/OFQ) in the dorsal raphe nucleus (DR) and frontal cortex (FC). N/OFQ and nociceptin opioid peptide (NOP) receptor are found in the DR and its terminals in the frontal cortex, medial and lateral septum, hippocampus, striatum, and nucleus accumbens. Although it is not clear whether N/OFQ is present in 5-HT neurons in the DR, NOP receptor in the $\mathrm{DR}$ is supposed to be located on $5-\mathrm{HT}$ neurons because the injection of 5,7-dihydroxytryptamine, neurotoxin which preferentially destroys 5-HT neurons, into rat DR significantly reduces $\left[{ }^{3} \mathrm{H}\right]$ nociceptin binding and $\left[{ }^{3} \mathrm{H}\right]$ citalopram binding. N/OFQ seems to exert biphasic effect on 5-HT neurons in the DR: 5-HT neurons in the DR is tonically inhibited by nearby GABAergic interneurons. Low doses of N/OFQ are found to stimulate 5-HT neurons, and it is likely that low doses of N/OFQ hyperpolarize GABA neurons, thereby disinhibiting 5-HT neurons in the DR. On the contrary, high doses of N/ OFQ inhibits 5-HT neurons by activating inwardly rectifying $\mathrm{K}^{+}$channels through NOP receptor. This effect appears to predominate over GABAergic disinhibition effects on 5-HT neurons in the DR. This scheme is modified using Motifolio Scientific Illustration Toolkits for Presentations and Publications (www.motifolio.com).

Although disparity between these results might be derived from the differences in experimental methods, further studies will be needed to resolve this ambiguity.

In the cerebral cortex, $5-\mathrm{HT}$ is present in nerve terminals and N/OFQ seems to regulate 5-HT release through presynaptic NOP receptor on serotonergic nerve terminals based on the finding that $\mathrm{N} / \mathrm{OFQ}$ inhibits 5-HT release in synaptosomes from frontal cortex [82]. N/OFQ inhibits not only spontaneous $\left.{ }^{3} \mathrm{H}\right] 5-\mathrm{HT}$ release but also $\mathrm{K}^{+}$-evoked release in the synaptosomes from rat frontoparietal cortex in a concentration-dependent fashion. The decrease in $\mathrm{K}^{+}$-evoked $\left.{ }^{3} \mathrm{H}\right] 5-\mathrm{HT}$ release by N/OFQ is blocked by [Nphe ${ }^{1} \mathrm{NC}(1-13) \mathrm{NH}_{2}$. Similarly, N/OFQ inhibits spontaneousand $\mathrm{K}^{+}$-evoked $\left.{ }^{3} \mathrm{H}\right] 5-\mathrm{HT}$ release in rat neocortical synaptosomes, and this inhibition is antagonized by different NOP receptor antagonists such as [Nphe ${ }^{1} \mathrm{NC}(1-13) \mathrm{NH}_{2}$, UFP-101, J-113397, and JTC-801 $[56,83]$. The inhibitory effect of N/OFQ on 5-HT release in synaptosomes is also replicated in experiments using brain slices in which N/OFQ reduces electrical stimulation-induced $\left[{ }^{3} \mathrm{H}\right] 5-\mathrm{HT}$ release in neocortical slice of mice [84], rat $[54,85]$ and human [85], and this effect is suppressed by partial NOP receptor agonist, $[\mathrm{F} / \mathrm{G}] \mathrm{NC}(1-13) \mathrm{NH}_{2}[54]$ and $\mathrm{NOP}$ receptor antagonist, J-113397 [85]. Moreover, per oral administration of LY2940094, NOP receptor antagonist, increases extracellular levels of 5-HT in rat PFC [5]. These results suggest that N/OFQ inhibits 5-HT release in the cerebral cortex through NOP receptor on serotonergic nerve terminals, but the role of NOP receptor in the DR 
for regulation of 5-HT release in the PFC is not clear. In addition to cerebral cortex, infusion of different concentrations of N/OFQ into the nucleus accumbens of freely moving rats decreases 5-HT release in a concentration-dependent fashion [80]. Interestingly, N/OFQ infusion into the DR also decreases 5-HT release in the nucleus accumbens. These results suggest that N/OFQ regulates 5 -HT release in the nucleus accumbens through NOP receptor both in the DR and/or on the serotonergic nerve terminals in the nucleus accumbens.

N/OFQ appears to be involved in forced swim-induced inhibition of 5-HT release in the DR. For example, electrical stimulation-induced $\left[{ }^{3} \mathrm{H}\right] 5$-HT release in DR slices obtained in rats shortly after forced swim is significantly lower than that in unstressed rats, and this effect is blunted by UFP-101 pretreatment [79]. Moreover, N/OFQ inhibits firing rate of presumably 5-HT neurons in the DR in a dose-dependent manner in DR slices, and the inhibitory effect of N/OFQ is significantly potentiated by prior forced swim such that even one-tenth N/OFQ dose in stressed rats inhibits the firing rate of DR neurons to a similar degree as in unstressed rats. Although stress-induced potentiation of N/OFQ inhibition on 5-HT release may be ascribed to NOP receptor upregulation after forced swim, it is unlikely because the number and affinity of NOP receptor in the DR is not changed after forced swim [78]. Rather, stress-induced potentiation of N/ OFQ effects seems to be mediated by corticotropin releasing factor (CRF) release and subsequent CRF1 receptor activation, since pretreatment of antalarmin, a selective CRF1 antagonist, 1 $h$ before forced swim shifts the N/OFQ concentration-response curve to the right in DR slices, indicating the blockade of N/OFQ effects. The results of in vitro DR slices suggests that CRF release and subsequent CRF1 receptor activation could result in stressinduced potentiation of N/OFQ effects in the DR.

Not only in vitro but also in vivo studies suggest that stressinduced potentiation of N/OFQ effects may be attributable to CRF release in the DR during stress. For example, single unit extracellular recording in the DR of anesthetized rats shows that intra-raphe injection of low dose N/OFQ inhibits the firing rate of DR neurons in unstressed rats and in rats subjected to forced swim $24 \mathrm{~h}$ before N/OFQ injection by $20 \%$ and $40 \%$, respectively [78]. Stress-induced potentiation of N/OFQ effects is mimicked by prior intra-raphe injection of ovine CRF $1 \mathrm{~h}$ before N/OFQ injection. Moreover, prior treatment with NBI 30755, a selective CRF1 receptor antagonist, reverses N/OFQ-induced inhibition in stressed rats to a level not significantly different from unstressed rats. These results suggest that N/OFQ-induced decrease in 5 -HT release in the DR is mediated by NOP receptor activation on 5-HT neurons in the DR under basal condition [79], but CRF release under the stress condition may potentiate the inhibitory effect of N/OFQ on presumably 5-HT neurons in the DR via activation of CRF1 receptors [78]. The regulation of monoamine neurotransmission by N/OFQ is summarized in Table 2 .

\section{N/OFQ AND HYPOTHALAMO-PITUITARY- ADRENAL (HPA) AXIS}

N/OFQ activates the HPA axis in rats under basal, unstressed conditions in that icv injection of N/OFQ increases plasma adrenocorticotropic hormone (ACTH) levels reaching a peak $30 \mathrm{~min}$ later [86], and then returns to basal levels around $60 \mathrm{~min}$ after the injection [87]. The magnitude of ACTH increase at $30 \mathrm{~min}$ after icv injection is dependent on N/OFQ doses. Similar timeand dose-dependent changes in plasma corticosterone levels are observed in rats after icv injection of N/OFQ [86-88]. Corticosterone appears to respond more sensitively to N/OFQ than ACTH, because the magnitude of increase in plasma corticosterone by $0.1 \mathrm{nmol} \mathrm{N} / \mathrm{OFQ}$ is similar to that in plasma ACTH by $1 \mathrm{nmol} \mathrm{N} /$ OFQ [86]. On the contrary, icv injection of N/OFQ in mice also increases plasma corticosterone levels, but the increase is significantly lower than that of controls given icv injection of saline [89]. Therefore, it seems likely that N/OFQ exerts an inhibitory effect on HPA axis response in mice, in contrast to a facilitatory role of N/OFQ observed in rats. Such seemingly discordant results appear to reflect differences in experimental procedures. In experiments with rats, icv injection of N/OFQ is mostly accomplished through cannulas implanted 3-11 days before the experiment $[87,88,90]$, whereas, in experiments with mice, icv injection of $\mathrm{N} /$ OFQ is performed through direct injection into the lateral ventricle in manually immobilized mice [89]. Moreover, direct injection of saline, used as vehicle in an experiment with mice [89] instead

Table 2. Regulation of monoamine neurotransmission by N/OFQ

\begin{tabular}{|c|c|}
\hline Norepinephrine & $\begin{array}{l}\text { Activate inwardly rectifying } \mathrm{K}^{+} \text {channels in } \mathrm{LC} \text { neurons } \\
\text { Inhibit NE release in the } \mathrm{LC} \text { and its terminals including BLA and PFC } \\
\text { Inhibit NE release in the cerebral cortex }\end{array}$ \\
\hline Dopamine & $\begin{array}{l}\text { Inhibit DA release in the nucleus accumbens } \\
\text { Inhibit DA synthesis in the nucleus accumbens by suppressing } \mathrm{Ser}^{40} \text { tyrosine hydroxylase } \\
\text { Suppress DA release in the nucleus accumbens induced by systemic cocaine injection }\end{array}$ \\
\hline Serotonin & $\begin{array}{l}\text { Activate inwardly rectifying } \mathrm{K}^{+} \text {conductance in the DR neurons and reduces firing rate of putative } 5-\mathrm{HT} \text { neurons } \\
\text { Reduce } 5-\mathrm{HT} \text { release in the DR and their terminals including cerebral cortex and nucleus accumbens }\end{array}$ \\
\hline
\end{tabular}

N/OFQ, nociceptin/orphanin FQ; LC, locus coeruleus; NE, norepinephrine; BLA, basolateral amygdala; PFC, prefrontal cortex; DA, dopamine; DR, dorsal raphe; 5-HT, 5-hydroxytryptamine. 
of dissolving N/OFQ in artificial cerebrospinal fluid (aCSF) in experiments with rats $[87,90]$ into the lateral ventricle in manually immobilized mice could act as a severe stress stimulus, as noted by authors [89], making conclusive interpretation difficult.

While N/OFQ primarily plays a facilitative role in the HPA axis in response to basal, unstressed conditions, it tightly regulates the response in a different manner under stressed conditions. Under mild stress conditions, only a high dose of N/OFQ augments HPA axis response, whereas, under severe stress conditions, varying doses of N/OFQ are without effect on HPA axis response. For example, when rats were exposed to mild stress such as novel environment for 15 or $30 \mathrm{~min}$ (novelty stress) and then sacrificed immediately, icv injection of aCSF just before stress increases plasma ACTH and corticosterone levels after the stress for $15 \mathrm{~min}$ [86]. Increased plasma ACTH appears to maintain levels until 30 min after novelty stress but increased plasma corticosterone declines to basal levels $30 \mathrm{~min}$ later. This time-dependent changes in plasma ACTH and corticosterone levels are unaffected by icv injection of low doses of N/OFQ ( 0.01 and $0.1 \mathrm{nmol})$ prior to novelty stress. In contrast, icv injection of a high dose of N/OFQ (1 nmol) significantly increases plasma ACTH and corticosterone levels at $15 \mathrm{~min}$ and $30 \mathrm{~min}$ after novelty stress, respectively. Similar facilitative role of N/OFQ under the condition of mild stress had been observed wherein icv injection of N/OFQ significantly augments the increase in plasma corticosterone levels in response to open field stress relative to aCSF-injected controls [90,91]. In contrast to the enhancement of HPA axis response under mild stress conditions, N/OFQ does not potentiate the HPA axis response under the severe stress such as restraint stress because there are no significant differences in plasma ACTH and corticosterone levels among the groups received either aCSF or varying doses of N/OFQ $(0.01,0.10$ and $1.00 \mathrm{nmol})$ [86]. The absence of N/OFQinduced potentiation of HPA axis response may be ascribed to a ceiling effect under the severe stress.

Although icv injection of N/OFQ tends to enhance HPA axis response, but it is not clear which brain areas are involved in the enhancement of HPA axis response. One plausible approach to solve this problem is to assess the c-Fos expression after icv injection of N/OFQ. It has been shown that icv injection of N/OFQ in rats and mice significantly increases c-Fos expression in the hypothalamic paraventricular nucleus, paraventricular thalamus, lateral septum, dorsomedial hypothalamus, nucleus tractus solitarius, central nucleus of the amygdala, and organum vasculosum of the lamina terminalis compared to the saline-injected controls [92-94]. Among these regions, the hypothalamic paraventricular nucleus, paraventricular thalamus, lateral septum, dorsomedial hypothalamus, and nucleus tractus solitarius are the brain areas that express both NOP receptor mRNA and ${ }^{125} \mathrm{I}-\left[{ }^{14} \mathrm{Tyr}\right]-$ OFQ binding, while central nucleus of the amygdala expresses low NOP receptor mRNA with no ${ }^{125} \mathrm{I}-\left[{ }^{14} \mathrm{Tyr}\right]-\mathrm{OFQ}$ binding [16]. Although low expression levels of NOP receptor mRNA and ${ }^{125} \mathrm{I}-$ $\left[{ }^{14} \mathrm{Tyr}\right]-\mathrm{OFQ}$ binding are found in brain areas around the orga- num vasculosum of the lamina terminalis such as anteroventral periventricular nucleus and anterior median preoptic nucleus, respectively, little is known about NOP mRNA and N/OFQ binding in the organum vasculosum of the lamina terminalis. Among these brain areas, hypothalamic paraventricular nucleus may play an important role in the enhancement of HPA axis response by $\mathrm{N} / \mathrm{OFQ}$. In line with this assumption, icv injection of N/OFQ increases mRNA levels of CRF and pro-opiomelanocortin (POMC) in the hypothalamic paraventricular nucleus and anterior pituitary, respectively [87]. In addition, icv injection of UFP-101 with $\mathrm{N} / \mathrm{OFQ}$ significantly blocks the increase in plasma corticosterone levels elicited by N/OFQ, while UFP-101 alone shows no effect on plasma corticosterone levels. The inhibitory effect of UFP-101 appears to be mediated by changes in CRF and POMC, because UFP-101 blocks the N/OFQ-induced increase in mRNA levels of $\mathrm{CRF}$ and POMC in the hypothalamic paraventricular nucleus and pituitary gland, respectively. In addition to the PVN, bed nucleus of the stria terminalis could be involved in the enhancement of HPA axis response by N/OFQ, because there is a report that N/ OFQ injection into the bed nucleus of the stria terminalis significantly increases plasma corticosterone levels, but this increase is not observed following N/OFQ injection into the amygdala [91]. Low NOP receptor mRNA with no ${ }^{125} \mathrm{I}-\left[{ }^{14} \mathrm{Tyr}\right]$-OFQ binding in the central nucleus of the amygdala may account for the lack of N/OFQ effects [16]. On the basis of these findings, it seems likely that hypothalamic paraventricular nucleus and bed nucleus of the stria terminalis are involved in HPA axis response to N/OFQ.

\section{N/OFQ AND STRESS}

Stress alters N/OFQ and NOP receptor expression in stressresponsive areas of brain depending on the type and duration of stress, sacrifice time points after stress, and the level of stress before the sacrifice. In the hypothalamus, acute stress changes N/ OFQ and NOP receptor mRNA expression. For example, acute systemic stress with a single administration of lipopolysaccharide (LPS) in rats increases prepro-N/OFQ mRNA expression in the hypothalamus $4 \mathrm{~h}$ later, but does not affect NOP receptor mRNA expression [95]. Similar increase of prepro-N/OFQ mRNA expression in the hypothalamus is observed $2 \mathrm{~h}$ after systemic injection of Staphylococcal enterotoxin A (SEA) to mice [96]. However, acute processive stress such as restraint stress for $120 \mathrm{~min}$ in rats exerts no effect on N/OFQ immunoreactivity in the hypothalamus shortly after stress [97], consistent with a finding that acute restraint for $60 \mathrm{~min}$ fails to alter prepro-N/OFQ and NOP receptor mRNA expression in the hypothalamus $3 \mathrm{~h}$ later [98]. In contrast to acute restraint stress, acute social defeat stress for 10 $\mathrm{min}$ in rats with or without preexposure to repeated social defeat for 5 days also increases NOP receptor mRNA expression, but not prepro-N/OFQ, in the hypothalamic paraventricular nucleus 3 $\mathrm{h}$ after the start of defeat [99]. Interestingly, the increase of NOP 
receptor mRNA expression by acute social defeat stress is also observed in the central nucleus of the amygdala and basomedial amygdala, but the increase is only evident in the hypothalamic paraventricular nucleus with repeated social defeat for 5 days. The persistent elevation of NOP receptor mRNA expression in the hypothalamic paraventricular nucleus with lack of changes in the central nucleus of the amygdala is congruent with the findings that a single social defeat increases c-Fos expression in the hypothalamic paraventricular nucleus and central nucleus of the amygdala, but the increase of c-Fos expression in the central nucleus of the amygdala, unlike hypothalamic paraventricular nucleus, is no longer apparent after repeated social defeat [100]. The increase in NOP receptor expression in the hypothalamic paraventricular nucleus may be attributable to stress-induced increase in plasma corticosterone, because exposure to dexamethasone during the neonatal period increases NOP receptor mRNA expression in the hypothalamic paraventricular nucleus [16] and there are potential glucocorticoid receptor binding sites on the promoter region of NOP receptor gene [101].

In the hippocampus, acute stress changes the expression of $\mathrm{N} /$ OFQ, but not NOP receptor. Acute restraint stress for $120 \mathrm{~min}$ in rats increases N/OFQ immunoreactivity in the CA1, CA3 and dentate gyrus of hippocampus shortly after restraint [97] while similar acute restraint stress for $60 \mathrm{~min}$ [98] and social defeat stress for $10 \mathrm{~min}$ [99] in rats fail to alter mRNA expression of prepro-N/OFQ or NOP receptor in the hippocampus $3 \mathrm{~h}$ after stress onset. Other lines of evidence show that acute systemic stress by injection of lipopolysaccharide in rats [95] or Staphylococcal enterotoxin A in mice [96] produces no significant change in mRNA expression of prepro-N/OFQ or NOP receptor in the hippocampus between 2 and $4 \mathrm{~h}$ after stress onset. These results suggest that acute processive stress of long duration (restraint stress for $120 \mathrm{~min}$ ) is enough to increase N/OFQ peptide levels in the hippocampus, but NOP receptor in the hippocampus is relatively unresponsive to stress. The increase in $\mathrm{N} / \mathrm{OFQ}$ expression in the hippocampus after stress appear to be mediated by elevation of plasma corticosterone based on the finding that subcutaneous injection of corticosterone $(1 \mathrm{mg} / \mathrm{kg})$ in rats, a dose chosen to mimic the plasma corticosterone concentrations observed in response to acute restraint stress, significantly increases N/OFQ immunoreactivity in the CA1, CA3 and dentate gyrus of hippocampus [97]. Moreover, many potential glucocorticoid receptor binding sites on the promoter region of prepro-N/OFQ human gene [102] further support the idea that changes in plasma corticosterone could regulate $\mathrm{N} / \mathrm{OFQ}$ expression in the hippocampus. Conversely, adrenalectomy has no impact on constitutive N/OFQ immunoreactivity in the hippocampus, but adrenalectomy blocks the acute restraint stress-induced increase in N/OFQ immunoreactivity [97]. These results suggest that endogenous corticosterone does not influence tonic N/OFQ expression in the hippocampus, but acute stress-induced increase in plasma corticosterone could mediate phasic N/OFQ expression after stress.
In the amygdala, acute social defeat stress for $10 \mathrm{~min}$ in rats significantly increases NOP receptor mRNA expression in the central and basomedial nuclei of amygdala, but not in the basolateral amygdala $3 \mathrm{~h}$ after the start of defeat session [99]. No significant change in prepro-N/OFQ mRNA is observed in these nuclei of amygdala. On the contrary, a short single housing for $30 \mathrm{~min}$ in rats on postnatal day 29 , enough to induce a stress response as manifested by significantly elevated plasma corticosterone levels, increases N/OFQ peptide levels in the amygdala as well as in the medial PFC and nucleus accumbens shortly after stress [103]. In addition to brain areas described above, acute stress alters the $\mathrm{N} /$ OFQ and NOP receptor expression in other brain areas. For example, LPS treatment significantly reduces NOP receptor mRNA expression in basal forebrain $4 \mathrm{~h}$ after LPS injection [95]. The reduced NOP receptor mRNA expression may reflect a response to increased N/OFQ release in the BNST [95] because NOP receptor mRNA expression in the BNST is higher than that in other brain areas [16] and LPS treatment induces neuronal activation of BNST, as evidenced by an increase in c-Fos expression [104]. Consistent with this finding, a single restraint stress for $30 \mathrm{~min}$ alone or after chronic variable stress including foot shock, cold room, restraint, and other stressor for 10 days significantly decreases the $\mathrm{N} / \mathrm{OFQ}$ peptide levels in the basal forebrain, which may be secondary to increased release of N/OFQ during stress [105].

Chronic stress over a period of less than 10 days appears not to alter N/OFQ and NOP receptor expression in brain, but chronic stress over 13 days tends to increase N/OFQ and NOP receptor expression. For example, prolonged single housing for 7 days from post-natal day 22 [103] and chronic variable stress for 10 days [105] produce no significant effect on N/OFQ peptide levels when measured during stress and $20 \mathrm{~h}$ after the last stressor, respectively. Repeated social defeat for 5 days does not alter prepro-N/OFQ and NOP receptor mRNA expression in the brain $3 \mathrm{~h}$ after the start of social defeat [99]. In contrast, repeated restraint for 13 or 14 day significantly increases prepro-N/OFQ mRNA expression in the BNST and reticular thalamic nucleus $3 \mathrm{~h}$ after restraint, but there is no change in NOP receptor mRNA expression [98]. In addition, daily maternal separation for $360 \mathrm{~min}$ in rat litters for 3 postnatal weeks (MS360) increases N/OFQ peptide levels in the periaqueductal gray when measured 7 weeks after maternal separation procedures [106]. Although MS360 also increases N/OFQ peptide levels in the hypothalamus when measured 7 weeks after the start of maternal separation procedures [106], the observed increase in the hypothalamus can be attributed to the stress from neonatal manipulation rather than that from the maternal separation itself, since daily handling for $15 \mathrm{~min}$ in rat litters for 3 weeks alone increases N/OFQ peptide levels in the hypothalamus. A similar trend of increase in N/OFQ and NOP receptor expression is observed in mice after chronic stress [107]. Chronic social crowding stress by housing $7 \mathrm{CBy}$ mice in a cage from 3 weeks of age for 13 weeks significantly increases N/OFQ and NOP receptor mRNA expression in the hippocampus compared to control mice 
housed individually, but this effect is not observed in 129S2 and B6 mice. Interestingly, prepro-N/OFQ and NOP receptor mRNA expression in the hippocampus does not differ between mouse strains (CBy, 129S2 and B6 mice) under individual housing condition. As CBy mice tend to be devoid of anxiety-like behavior relative to $129 \mathrm{~S} 2$ and $\mathrm{B} 6$ mice, it is thought that increased N/OFQ and NOP receptor mRNA expression in the hippocampus of CBy mice may be one of possible compensatory mechanisms to reduce anxiety-like behavior.

\section{N/OFQ AND DENDRITIC OUTGROWTH IN THE HIPPOCAMPUS}

N/OFQ and NOP receptor are moderately expressed in pyramidal cells of CA1 and CA3, dentate granule cells, and interneurons within the hippocampus $[15,16,76]$. N/OFQ reduces the number and branch points of primary dendrites in cultured hippocampal neurons [108]. Conversely, BDNF increases the number and branch points of primary dendrites, and this dendritic outgrowth is significantly attenuated by N/OFQ pretreatment. Moreover, in vivo Golgi staining of N/OFQ knockout mice shows significant increases in number and length of primary dendrites in the dentate granule cells. These results suggest that N/OFQ inhibits dendritic outgrowth in the hippocampus and opposes the BDNFinduced increase in dendritic outgrowth.

The inhibition of dendritic outgrowth by N/OFQ in the hippocampus is intriguing because BDNF induces ppN/OFQ mRNA expression in cultured hippocampal cells, and N/OFQ treatment not only induces immediate early genes implicated in neurite extension and morphologic alteration but also increases number and length of neurites per neuron [109]. These seemingly contrasting results by Ring et al. [109] and Alder et al. [108] could be explained by differences in experimental procedures. Notably, N/ OFQ was treated in cultured hippocampal cells for $24 \mathrm{~h}$ in a previous study [109], instead of several days in a latter study [108]. It seems likely that cultured hippocampal cells treated with N/OFQ for $24 \mathrm{~h}$ may not be mature enough to develop connections, since protrusion, extension, and maturation of primary dendrites take several days to a week [108]. Moreover, a previous study by Ring et al. [109] fails to distinguish between inhibitory interneurons and excitatory pyramidal cells in the hippocampus and measures neurite outgrowth irrespective of cell types [108], while a latter study by Alder et al. [108] counts only dendritic outgrowth of excitatory pyramidal cells.

Considering that N/OFQ attenuates the BDNF-induced increase in number and branch points of primary dendrites, N/ OFQ may counteract BDNF effects through feedback interaction. This premise raises the possibility that BDNF treatment in hippocampal cells from NOP receptor knockout mice induces more robust increase in number and length of primary dendrites, because there is little negative feedback inhibition to BDNF ef- fects. However, BDNF has no potentiating effect on number and length of primary dendrites in hippocampal cells from NOP receptor knockout mice [108]. Moreover, N/OFQ does not further reduce the number and length of primary dendrites in cultured hippocampal cells pretreated with ANA-12, a TrkB receptor antagonist. These results suggest that N/OFQ and BDNF have distinctly different pathways to regulate primary dendritic outgrowth in the hippocampus. The inhibitory effect of N/OFQ on dendritic outgrowth in the hippocampus appears to be mediated by small GTPase Ras homologous member A (RhoA) activation, as N/OFQ transiently increases RhoA activation in cultured hippocampal neurons and N/OFQ-induced decrease in number and length of primary dendrites is recovered by pretreatment with $\mathrm{C} 3$ transferase, a RhoA inhibitor [108]. If N/OFQ reduces the number and length of primary dendrites in the hippocampus, it is probable that NOP receptor antagonists could increases dendritic outgrowth. Although treatment with naloxone, nonselective NOP receptor antagonist, increases the number of primary dendrites in cultured hippocampal neurons [108], as of yet, the effect of NOP receptor antagonists on dendritic outgrowth under basal conditions has not been explored.

\section{ANTIDEPRESSANT-LIKE EFFECTS OF NOP RECEPTOR ANTAGONISTS}

NOP receptor antagonists show antidepressant-like effects in different animal models of depression. Prior icv injection of peptide NOP receptor antagonists, $\left[\mathrm{Nphe}^{1}\right] \mathrm{N} / \mathrm{OFQ}(1-13)-\mathrm{NH}_{2}$ and UFP-101, into mice and rats reduces immobility in forced swim test (FST) in a dose-dependent manner, respectively $[50,110,111]$, an effect commonly observed after antidepressant treatment. The similar antidepressant-like effects are reproduced by systemic injection of non-peptide antagonists J-113397 and SB-612111 in mice as well [111-113]. Recent studies also demonstrate that LY2940094, a selective and orally bioavailable NOP receptor antagonist, significantly reduces immobility in the FST in mice [4,112] and rats [5]. Interestingly, LY2940094 in mice reduces immobility in the FST in a dose-dependent manner and the maximal effect by LY2940094 is equivalent to that obtained by imipramine [4]. The antidepressant-like effects seem to be mediated by NOP receptor, since antidepressant-like effects of LY2940094 in the FST are not observed in NOP receptor knockout mice. Furthermore, antidepressant-like effects of NOP receptor antagonists, including SB-612111 [113] and UFP-101 [110], in the FST are prevented by co-administration of N/OFQ. Similar antidepressant-like effects of NOP receptor antagonists has been demonstrated in tail suspension test (TST) in mice. For example, SB-612111 significantly reduces immobility in mice [113]. Likewise, icv injection of UFP-101 reduces the immobility in the TST in a dose-dependent manner, and co-administration of N/OFQ fully prevents the antidepressant-like effects induced by UFP-101 
[50], recapitulating again the involvement of NOP receptor in the antidepressant-like effects of NOP receptor antagonists.

In addition to FST and TST, NOP receptor antagonists also relieve learned helplessness. For example, NOP receptor antagonists such as SB-612111 and UFP-101 not only reduce escape latencies but also increase the number of escapes robustly in the learned helpless models of mice $[112,114]$. The antidepressant-like effects of NOP receptor antagonists are also found in other animal models of depression. Intraperitoneal injection of LPS in mice induces depression-like behavior as demonstrated by an increase in immobility in the TST observed $24 \mathrm{~h}$ after injection [115]. The depression-like behavior by LPS is not observed in NOP receptor knockout mice, unlike in wild type mice, suggesting that LPSinduced depression-like behavior appears to be mediated by NOP receptor. Moreover, SB-612111 and UFP-101, when injected 5 and $30 \mathrm{~min}$ before the TST, respectively, significantly reverse increased immobility induced by LPS [115]. Interestingly, SB612111, injected $30 \mathrm{~min}$ before LPS injection instead of $5 \mathrm{~min}$ before TST, has no significant effect on immobility in the TST observed $24 \mathrm{~h}$ later. This result suggests that N/OFQ-NOP receptor signaling in the TST is more likely to be engaged in the expression of depression-like behavior such as increased immobility by LPS rather than in the development of depression-like behavior [115].

Evidence also demonstrates that chronic administration of NOP receptor antagonists relieve depression-like behavior induced by chronic mild stress (CMS). CMS exposure for 11-12 weeks in male Wistar rats (from 180-200 g) elicits depression-like behavior, as manifested by reduced sucrose intake in sucrose preference and increased immobility in the FST $[116,117]$. Daily treatment with either varying doses of UFP-101 $(5,10$, or $20 \mathrm{nmol}$, icv) or other antidepressants such as fluoxetine or imipramine over 3 weeks, started from 9 weeks of CMS exposure, restores sucrose intake level comparable to that of unstressed controls. Similar findings are observed in the FST in which CMS exposure for 11 weeks significantly increases immobility, but decreases swimming and climbing, all of which are reverted by daily treatment with UFP-101 or other antidepressants over 3 weeks. Interestingly, antidepressant-like effects of UFP-101 in sucrose intake test and FST is reversed by coadministration of N/OFQ with UFP101. This result suggests that NOP receptor is involved in the antidepressant-like effects of chronic UFP-101 treatment in CMS model of depression.

\section{POSSIBLE ROLES OF N/OFQ IN DEPRESSION}

Preclinical and clinical studies have shown that NOP receptor antagonists show antidepressant-like effects. Based on these findings, it is plausible that increased N/OFQ neurotransmission is involved in depression, but there is only paucity of clinical studies describing changes of plasma N/OFQ in patients with depres- sion. For example, clinical studies conducted in China demonstrated that plasma N/OFQ and 5-HT levels are significantly increased and decreased in patients with postpartum depression, respectively [118]. Notably, they reported that there is an inverse correlation between plasma N/OFQ and 5-HT levels. Moreover, plasma N/OFQ seems to be significantly increased in patients with bipolar depressive disorder and elevated plasma N/OFQ levels are positively correlated with Hamilton Depression Scale and Montgomery and Asberg Depression Rating Scale, two widely used depression scales [119]. In contrast to clinical studies, there is few study observing the changes of N/OFQ in brain and blood in animal models of depression such as CMS. Instead of observing changes of N/OFQ levels in brain and blood in animal models of depression, it has been tested whether exogenous N/OFQ induces depression-like behavioral effects in the FST and TST. Unexpectedly, icv injection of N/OFQ in mice fails to augment the immobility in the FST per se [111], while N/OFQ reverses the decrease in immobility induced by NOP receptor antagonists when given as a combination $[110,113]$. Although it is possible that the lack of N/OFQ effects for increasing immobility may be attributable to relatively high baseline immobility in one study [111], other lines of evidence demonstrate that N/OFQ, SR-8993 and RO 65-6570, NOP receptor agonists, show no significant effect on the baseline immobility in the FST $[112,120]$. Moreover, N/OFQ and RO-6570 are found not to affect baseline immobility or helpless behavior such as escape latency and number of escapes in the in the TST and $\mathrm{LH}$, respectively $[110,112]$. These results suggest that N/OFQNOP signaling may be fully activated during the FST, TST, and $\mathrm{LH}$, and thus exogenous N/OFQ administration may not affect baseline behavior in the FST, TST or LH, indicating a ceiling effect. However, fully activated N/OFQ-NOP signaling during the FST, TST, and LH, leading to depression-like behavior, appears to be blocked by NOP receptor antagonists, demonstrating antidepressant-like effects.

\section{POSSIBLE ANTIDEPRESSANT MECHANISM OF NOP RECEPTOR ANTAGONISTS}

Mounting evidence has shown that monoamine deficiency, dysregulation of HPA axis, and impairment of neurotrophin and neurogenesis may be possible mechanism underlying depression $[121,122]$. Therefore, NOP receptor antagonists could exert antidepressant-like effects through normalization of mechanisms associated with depression.

Involvement of monoaminergic neurotransmission in antidepressant-like effects of NOP receptor antagonists

UFP-101 exerts antidepressant-like effects in the FST and TST, 
most commonly used rodent models for antidepressants screening [50]. Considering the inhibitory role of N/OFQ for monoaminergic neurotransmission, it is conceivable that NOP receptor antagonists may display antidepressant-like effects by enhancing monoaminergic neurotransmission. However, it is unclear which monoamine is more involved in antidepressant-like effects of NOP receptor antagonists in animal models of depression. As single icv injection of UFP-101 significantly increases the time spent in climbing, but not swimming in the FST [50], it seems likely that antidepressant-like effects of UFP-101 resembles those of selective NE reuptake inhibitors more closely than those of selective serotonin reuptake inhibitors because selective NE reuptake inhibitors and selective serotonin reuptake inhibitors tends to increase climbing and swimming in the FST, respectively [123]. Intriguingly, prior DSP-4 treatment, which results in depletion of brain NE, does not affect antidepressant-like effects of UFP-101 in the FST, whereas prior PCPA treatment, which results in depletion of brain 5-HT, partially blunts the antidepressant-like effects of UFP-101 [50]. This result suggests that 5-HT may play more important roles in the antidepressant-like effects of UFP-101 than NE, despite the finding that UFP-101 increases climbing in the FST.

Nevertheless, the absence of any influence of DSP-4 treatment on antidepressant-like effects produced by UFP-101 does not necessarily mean that NE may not be involved in the antidepressantlike effects of UFP-101 [50], because same DSP-4 treatment does not block but rather potentiate antidepressant-like effects in the FST by reboxetine, one of the most selective NE reuptake inhibitor [123]. The absence of DSP-4 effect in the antidepressant-like effects of reboxetine is presumably attributable to relatively more increase in NE release from remaining intact noradrenergic nerve terminals because extracellular NE concentration in the frontal cortex is two-fold higher in DSP-4 treated rats than in vehicle treated rats, although DSP-4 significantly reduces NE content of frontal cortex by 75\% [124]. Alternatively, DSP-4 is known to damage preferentially dorsal noradrenergic bundles, consisting of noradrenergic neurons in the LC whose axon terminals are located in the frontal cortex, hippocampus, amygdala, and cerebellum, but it is possible that other noradrenergic pathway plays a more crucial role in the antidepressant-like effects than does dorsal noradrenergic bundles. Indeed, lesion of ventral noradrenergic bundle, from lateral tegmentum to hypothalamus, septum, central nucleus of the amygdala, and bed nucleus of the stria terminalis, by 6-OHDA, a neurotoxin that selectively damages catecholaminergic neurons, abolishes the antidepressantlike effects of reboxetine in the FST [125], suggesting that intact ventral noradrenergic bundle may be required for antidepressantlike effects of reboxetine. Although used drug is limited to UFP101 in this experiment, it is inferred that enhanced serotonergic neurotransmission may be more involved in the antidepressantlike effects of UFP-101 in the FST, but NE and DA are also likely to be involved in the antidepressant-like effects of NOP receptor antagonists.

To assess the antidepressant-like effects of chronic UFP-101 treatment, rats are exposed to 11 weeks of CMS, are daily injected with different doses of UFP-101 (5, 10, or $20 \mathrm{nmol}$, icv) over 3 weeks from 9 weeks of CMS, and then sacrificed $24 \mathrm{~h}$ after the last drug administration [117]. CMS reduces and increases 5-HT levels in the frontal cortex and in the pons, respectively, while being ineffective in changing 5-HIAA in both areas. All doses of UFP101 treatment during CMS restores 5-HT levels in the frontal cortex and pons to basal levels of unstressed control. As 5-HIAA content in brain represents intraneuronal metabolism of 5-HT by monoamine oxidase [126], unaltered 5-HIAA may reflect no significant changes in 5-HT metabolism by the CMS and CMSinduced decrease in 5-HT content in the frontal cortex may be ascribed to reduced synthesis and/or increased release. Chronic stress appears to reduce 5-HT release in the frontal cortex, because basal extracellular levels of 5-HT in this brain area are significantly lower in rats exposed to chronic unavoidable stress for 3 weeks than in control rats [127]. Moreover, 5-HT accumulation obtained after cocaine administration in the frontal cortex is also significantly diminished in rats exposed to chronic unavoidable stress. Considering that cocaine blocks the reuptake of DA, 5-HT, and NE but does not affect their release, reduced 5-HT accumulation may represent that 5-HT synthesis in the frontal cortex is decreased by chronic unavoidable stress. Therefore, reduced 5-HT content in the frontal cortex may reflect reduced 5-HT synthesis by CMS, and chronic UFP-101 treatment appears to restore the reduced 5-HT synthesis in the frontal cortex.

In line with this assumption, reduced 5-HT neurotransmission may be one of the important contributing factors to depression [128]. Indeed, a brain imaging study showed that 5-HT synthesis is reduced in cingulate cortex, one of brain areas comprised frontal cortex, of depressed patients [129]. This result suggests that CMS-induced decrease in 5-HT levels in the frontal cortex [117] may contribute, in part, to depressive-like behavior as shown by reduced sucrose intake and increased immobility in the FST observed after CMS. Conversely, reinstitution of decreased 5-HT in the frontal cortex by UFP-101 could be involved in antidepressant-like effects. Together, these results raise the possibility that NOP receptor antagonists induce antidepressant-like effects by restoration of reduced 5-HT in the frontal cortex.

\section{NOP receptor antagonists, neurotrophins, and neurogenesis}

Brain imaging studies demonstrate that the volume of frontal cortex and hippocampus is often reduced in patients with depression [130-132]. In support of these findings, postmortem studies of frontal cortex in depressed patients reveal reduced size of cortical neurons and glial cells with decreased number of synapses $[133,134]$. Similar atrophy of pyramidal neurons and granule cells with decreased soma size and neuropil, consist of dendritic spine 
and branching, proximal axons and glial processes, are observed in the hippocampus of depressed patients [135]. In particular, hippocampal gray matter volume is negatively correlated with the duration of depression went untreated [136]. In parallel to clinical studies, preclinical studies also show that chronic stress induces atrophy of pyramidal neurons in the frontal cortex and decreases neurogenesis and apical dendritic length and branch points in the CA3 in the hippocampus $[137,138]$. Conversely, antidepressants treatment tends to reverse chronic stress-induced changes. It has been suggested that reduced volume of frontal cortex and hippocampus in depression may be due to decreased neurotrophin expression and subsequent decrease in neurogenesis with neuronal and glial atrophy $[139,140]$. Evidence in support of this scheme has been provided by postmortem studies showing that BDNF levels are decreased in the hippocampus of depressed patients [141] and in the frontal cortex of teenage suicide victims [142]. Similar decrease in FGF2 mRNA levels is noted in the hippocampus of depressed patients [143]. In contrast, chronic antidepressant treatments increase BDNF and FGF2 in the hippocampus [144] and frontal cortex of postmortem brain samples [145], respectively. Consistent with clinical studies, preclinical studies demonstrate that injection of BDNF and FGF-2 into lateral ventricle, hippocampus, or frontal cortex elicits antidepressant-like effects in animal models of depression [137,146-149]. Chronic antidepressant treatments not only increase BDNF and FGF2 in the frontal cortex and hippocampus [150-152], but also block stress-induced decrease of BDNF in these brain areas [153]. Furthermore, BDNF is presumed to be necessary for antidepressant effects considering that antidepressant effects of desipramine and imipramine are not observed in inducible forebrain BDNF knockout mice [154] and heterozygous BDNF null (BDNF+/-) mice [155], respectively.

So far, relatively little is known about the role of neurotrophin and neurogenesis in the antidepressant-like effects of NOP receptor antagonists, but a recent study under the condition of CMS suggests that NOP receptor antagonists may exert antidepressantlike effects through modulation of FGF-2 in the hippocampus. CMS for 12 weeks decreases neuronal differentiation, and survival, but repeated injection of UFP-101 during CMS exposure, being ineffective in neuronal differentiation and survival by itself, reverts the decrease in neuronal differentiation and survival to normal, an effect that is blocked by co-administration of UFP-101 and N/OFQ [116]. CMS is also found to reduce the proliferation of neural stem cells in the dentate gyrus of hippocampus, and, interestingly, this effect is not affected by repeated injection of UFP-101. The protective effect of UFP-101 appears to be mediated largely by FGF-2, because CMS reduces FGF- 2 immunoreactivity in the hippocampus, and this reduction is reversed by chronic treatment with UFP-101 [116]. In contrast to FGF-2, repeated injection of UFP-101 has no impact on mRNA and protein levels of $\mathrm{BDNF}$ in the hippocampus regardless of the presence or absence of CMS. This result raises the possibility that UFP-101 exerts its antidepressant-like effects through the modulation of FGF-2. Sev- eral lines of evidence has shown that FGF-2 and its receptors are implicated in the pathophysiology of depression and mechanism underlying antidepressant effect. Repeated injection or chronic infusion of FGF-2 into lateral ventricle induces antidepressantlike effects in the FST and novelty-suppressed feeding, animal models to screen antidepressant efficacy $[147,149]$. Repeated social defeat in rats reduces the expression of FGF- 2 and FGFR1, a highaffinity receptor for FGF-2, in the subfields of hippocampus [149], while chronic desipramine and fluoxetine treatment increases levels of FGF-2 [150,151] and FGFR1 in the hippocampus [151]. Evidence also shows that FGF2 is required for the antidepressant effects because antidepressant effects by imipramine and fluoxetine in the chronic unpredictable stress and FST are blocked by chronic infusion or repeated injection of SU5402, an inhibitor of FGF-2 receptor signaling, to lateral ventricle [147]. Furthermore, antidepressant effects of fluoxetine in wild type mice under the condition of chronic variable stress are not observed in FGF2 knockout mice [156]. These results raise the possibility that enhancement of FGF-2/FGFR signaling in the hippocampus may be one of the possible mechanisms underlying antidepressant-like effects of NOP receptor antagonists.

\section{NOP receptor antagonists and HPA axis regulation}

Chronic stress, often precedes or precipitates depression, activates HPA axis and elevates plasma glucocorticoids. Therefore, HPA axis hyperactivity remains one of the most consistent findings observed in individuals with depression as manifested by elevated plasma and CSF concentrations of cortisol and nonsuppression of cortisol secretion after dexamethasone administration [157]. In agreement with clinical studies, chronic administration of corticosterone, the glucocorticoids in rodents, reduces sucrose preferences in rats [158] and sucrose intake in mice [159], both of which are validated measure of anhedonia. The depressive effect of corticosterone is also manifested in the FST and TST, where chronic administration of corticosterone increases immobility in rats [159] and mice [160], respectively. The increase in immobility appears to be dependent on the dose of corticosterone and is detectable only after repeated injection of corticosterone, but not after a single injection of corticosterone [161]. As a consequence, it is conceivable that the blockade of HPA axis by glucocorticoid receptor antagonist could show antidepressant effects. Indeed, mifepristone, glucocorticoid and progesterone receptor antagonist [162], and CORT 108927, pure glucocorticoid receptor antagonist [163], reduce immobility in the FST. Repeated mifepristone treatment for 7 days is also found to alleviate anhedonia induced by CMS for 3 weeks, as indicated by decreased sucrose preference [164]. Similar antidepressant effects of mifepristone are observed in psychotic depression where elevated serum cortisol levels are frequently noted and the symptoms of delusion, hallucination, and suicide attempts are prominent [165]. Moreover, glucocorticoids are closely interrelated to neurogenesis in the hippocam- 
pus. Exogenous administration of glucocorticoids to animals inhibits neuronal proliferation, differentiation, and survival, and mifepristone blunts the decreases in the neurogenesis in the hippocampus induced by glucocorticoids [166]. Interestingly, even 4 days of mifepristone treatment restores the reduction in differentiation and survival of neurons observed after 21 days of chronic unpredictable stress exposure [167] or corticosterone treatments [168].

Considering a stimulatory role for N/OFQ in the HPA axis response under the basal or mild stress conditions, it is probable that NOP receptor antagonists could exert antidepressant-like effects through the restoration of HPA axis hyperactivity. In support of this possibility, when rats are daily exposed to CMS for 8 weeks and subsequently given icv injection of either saline, UFP$101(5,10$, and $20 \mathrm{nmol})$ or co-treatment of UFP-101 (10 nmol) with N/OFQ (5 nmol) for 3 weeks, CMS exposure significantly increases plasma corticosterone levels, which is significantly blocked by repeated injection of UFP-101 in a dose-dependent manner [117]. The restoration of corticosterone to control levels by chronic UFP-101 treatment in CMS exposed rats is reinstated by co-treatment of UFP-101 with N/OFQ. These results raise the possibility that chronic stress presumably increases N/OFQ release [105], which in turn leads to the activation of HPA axis through NOP receptor. Interestingly, icv injection of UFP-101 (10 $\mathrm{nmol}$ ) alone shows no significant effect on plasma corticosterone levels in unstressed rats [117], a result that replicates a previous finding by Leggett et al. [95]. These results suggest that HPA axis response is not under the tonic inhibitory control by N/OFQ. Therefore, stress-induced increase in N/OFQ neurotransmission could enhance HPA axis response to stress, and NOP receptor antagonists could exert its antidepressant-like effects by alleviating the enhanced HPA axis response. As with the protective effect of UFP-101 in neurogenesis, normalization of HPA axis hyperactivity could contribute to antidepressant-like effects of NOP receptor antagonists.

\section{CONCLUSION}

N/OFQ and NOP receptor are found in brain areas implicated in major depressive disorder and in therapeutic effects of antidepressants. A number of study have attempted to reveal the mechanism underlying its antidepressant-like activity of NOP receptor antagonists. It became apparent that N/OFQ inhibits neuronal excitability of monoaminergic neurons and monoamine release from their terminals by activation of GIRK and inhibition of voltage sensitive calcium channels, respectively, and these effects are reversed by NOP receptor antagonists. It was likewise reported that N/OFQ facilitates HPA axis activity under the basal or mild stress condition and suppresses dendritic outgrowth in the hippocampus, while chronic NOP receptor antagonists not only inhibit CMS-induced increase in HPA axis activity but also block the CMS-induced decrease in neuronal survival and differentiation. Moreover, NOP receptor antagonists show antidepressantlike effects in many animal models of depression. Therefore, it is not surprising for a new oral NOP receptor antagonist to undergo clinical trials, and preliminary studies demonstrate some promising antidepressant activity. At present, many clinical trials are necessary to conclude that NOP receptor antagonists show antidepressant effects, but preclinical and clinical studies of N/OFQ and NOP receptor antagonists provide a stepping stone for the development of a novel antidepressant.

\section{ACKNOWLEDGEMENTS}

This work was supported by Student Research Program of Korea University College of Medicine.

\section{CONFLICTS OF INTEREST}

The authors declare no conflicts of interest.

\section{REFERENCES}

1. Lane RM. Antidepressant drug development: Focus on triple monoamine reuptake inhibition. J Psychopharmacol. 2015;29:526544.

2. Skolnick P, Krieter P, Tizzano J, Basile A, Popik P, Czobor P, Lippa A. Preclinical and clinical pharmacology of DOV 216,303, a "triple" reuptake inhibitor. CNS Drug Rev. 2006;12:123-134.

3. Chen Z, Yang J, Tobak A. Designing new treatments for depression and anxiety. IDrugs. 2008;11:189-197.

4. Witkin JM, Rorick-Kehn LM, Benvenga MJ, Adams BL, Gleason SD, Knitowski KM, Li X, Chaney S, Falcone JF, Smith JW, Foss J, Lloyd K, Catlow JT, McKinzie DL, Svensson KA, Barth VN, Toledo MA, Diaz N, Lafuente C, Jiménez A, et al. Preclinical findings predicting efficacy and side-effect profile of LY2940094, an antagonist of nociceptin receptors. Pharmacol Res Perspect. 2016;4:e00275.

5. Post A, Smart TS, Krikke-Workel J, Dawson GR, Harmer CJ, Browning M, Jackson K, Kakar R, Mohs R, Statnick M, Wafford K, McCarthy A, Barth V, Witkin JM. A selective nociceptin receptor antagonist to treat depression: evidence from preclinical and clinical studies. Neuropsychopharmacology. 2016;41:1803-1812.

6. Witkin JM, Wallace TL, Martin WJ. Therapeutic approaches for NOP receptor antagonists in neurobehavioral disorders: clinical studies in major depressive disorder and alcohol use disorder with BTRX-246040 (LY2940094). Handb Exp Pharmacol. 2019;254:399415.

7. Mollereau C, Parmentier M, Mailleux P, Butour JL, Moisand C, Chalon P, Caput D, Vassart G, Meunier JC. ORL1, a novel member of the opioid receptor family. Cloning, functional expression and localization. FEBS Lett. 1994;341:33-38.

8. Bunzow JR, Saez C, Mortrud M, Bouvier C, Williams JT, Low M, Grandy DK. Molecular cloning and tissue distribution of a puta- 
tive member of the rat opioid receptor gene family that is not a mu, delta or kappa opioid receptor type. FEBS Lett. 1994;347:284-288.

9. Chen Y, Fan Y, Liu J, Mestek A, Tian M, Kozak CA, Yu L. Molecular cloning, tissue distribution and chromosomal localization of a novel member of the opioid receptor gene family. FEBS Lett. 1994;347:279-283.

10. Osinski MA, Pampusch MS, Murtaugh MP, Brown DR. Cloning, expression and functional role of a nociceptin/orphanin FQ receptor in the porcine gastrointestinal tract. Eur J Pharmacol. 1999;365:281-289.

11. Meunier JC, Mollereau C, Toll L, Suaudeau C, Moisand C, Alvinerie P, Butour LC, Guillemot JC, Ferrara P, Monsarrat B, Mazarguil $\mathrm{H}$, Vassart G, Parmentier M, Costentin J. Isolation and structure of the endogenous agonist of opioid receptor-like $\mathrm{ORL}_{1}$ receptor. Nature. 1995;377:532-535.

12. Reinscheid RK, Nothacker HP, Bourson A, Ardati A, Henningsen RA, Bunzow JR, Grandy DK, Langen H, Monsma FJ Jr, Civelli O. Orphanin FQ: a neuropeptide that activates an opioidlike G protein-coupled receptor. Science. 1995;270:792-794.

13. Henderson G, McKnight AT. The orphan opioid receptor and its endogenous ligand--nociceptin/orphanin FQ. Trends Pharmacol Sci. 1997;18:293-300.

14. Gintzler AR, Adapa ID, Toll L, Medina VM, Wang L. Modulation of enkephalin release by nociceptin (orphanin FQ). Eur J Pharmacol. 1997;325:29-34.

15. Neal CR Jr, Mansour A, Reinscheid R, Nothacker HP, Civelli O, Watson SJ Jr. Localization of orphanin FQ (nociceptin) peptide and messenger RNA in the central nervous system of the rat. J Comp Neurol. 1999;406:503-547.

16. Neal CR Jr, Mansour A, Reinscheid R, Nothacker HP, Civelli O, Akil H, Watson SJ Jr. Opioid receptor-like (ORL1) receptor distribution in the rat central nervous system: comparison of ORL1 receptor mRNA expression with ${ }^{125} \mathrm{I}-\left[{ }^{14} \mathrm{Tyr}\right]$-orphanin FQ binding. $J$ Comp Neurol. 1999;412:563-605.

17. Mansour A, Fox CA, Akil H, Watson SJ. Opioid-receptor mRNA expression in the rat CNS: anatomical and functional implications. Trends Neurosci. 1995;18:22-29.

18. New DC, Wong YH. The ORL1 receptor: molecular pharmacology and signalling mechanisms. Neurosignals. 2002;11:197-212.

19. Donica CL, Awwad HO, Thakker DR, Standifer KM. Cellular mechanisms of nociceptin/orphanin FQ (N/OFQ) peptide (NOP) receptor regulation and heterologous regulation by N/OFQ. $\mathrm{Mol}$ Pharmacol. 2013;83:907-918.

20. Zhang Z, Xin SM, Wu GX, Zhang WB, Ma L, Pei G. Endogenous delta-opioid and ORL1 receptors couple to phosphorylation and activation of p38 MAPK in NG108-15 cells and this is regulated by protein kinase A and protein kinase C. J Neurochem. 1999;73:15021509.

21. Knoflach F, Reinscheid RK, Civelli O, Kemp JA. Modulation of voltage-gated calcium channels by orphanin FQ in freshly dissociated hippocampal neurons. J Neurosci. 1996;16:6657-6664.

22. Tallent MK, Madamba SG, Siggins GR. Nociceptin reduces epileptiform events in CA3 hippocampus via presynaptic and postsynaptic mechanisms. JNeurosci. 2001;21:6940-6948.

23. Levitan IB, Kaczmarek LK. The neuron: cell and molecular biology. 3rd ed. New York: Oxford University Press; 2001.

24. Chin JH, Harris K, MacTavish D, Jhamandas JH. Nociceptin/or- phanin FQ modulation of ionic conductances in rat basal forebrain neurons. J Pharmacol Exp Ther. 2002;303:188-195.

25. Qu L, Li Y, Tian H, Wang Z, Cui L, Jin H, Wang W, Yang L. Effects of $\mathrm{PKC}$ on inhibition of delayed rectifier potassium currents by N/ OFQ. Biochem Biophys Res Commun. 2007;356:582-586.

26. Yao WD, Wu CF. Distinct roles of CaMKII and PKA in regulation of firing patterns and $\mathrm{K}^{+}$currents in Drosophila neurons. J Neurophysiol. 2001;85:1384-1394.

27. Vaughan CW, Christie MJ. Increase by the ORL1 receptor (opioid receptor-like1) ligand, nociceptin, of inwardly rectifying $\mathrm{K}$ conductance in dorsal raphe nucleus neurones. Br J Pharmacol. 1996;117:1609-1611.

28. Connor M, Vaughan CW, Chieng B, Christie MJ. Nociceptin receptor coupling to a potassium conductance in rat locus coeruleus neurones in vitro. Br J Pharmacol. 1996;119:1614-1618.

29. Emmerson PJ, Miller RJ. Pre- and postsynaptic actions of opioid and orphan opioid agonists in the rat arcuate nucleus and ventromedial hypothalamus in vitro. J Physiol. 1999;517(Pt 2):431-445.

30. Wagner EJ, Rønnekleiv OK, Grandy DK, Kelly MJ. The peptide orphanin FQ inhibits beta-endorphin neurons and neurosecretory cells in the hypothalamic arcuate nucleus by activating an inwardly-rectifying K $\mathrm{K}^{+}$conductance. Neuroendocrinology. 1998;67:73-82.

31. Slugg RM, Rønnekleiv OK, Grandy DK, Kelly MJ. Activation of an inwardly rectifying $\mathrm{K}^{+}$conductance by orphanin-FQ/nociceptin in vasopressin-containing neurons. Neuroendocrinology. 1999;69:385-396.

32. Chiou LC. [Phe $\left.{ }^{1} \mathrm{psi}\left(\mathrm{CH}_{2}-\mathrm{NH}\right) \mathrm{Gly}^{2}\right]$ nociceptin-(1-13)- $\mathrm{NH}_{2}$ activation of an inward rectifier as a partial agonist of ORL1 receptors in rat periaqueductal gray. Br J Pharmacol. 1999;128:103-107.

33. Ikeda K, Kobayashi K, Kobayashi T, Ichikawa T, Kumanishi T, Kishida H, Yano R, Manabe T. Functional coupling of the nociceptin/orphanin FQ receptor with the G-protein-activated $\mathrm{K}^{+}$ (GIRK) channel. Brain Res Mol Brain Res. 1997;45:117-126.

34. Meis S, Pape HC. Postsynaptic mechanisms underlying responsiveness of amygdaloid neurons to nociceptin/orphanin FQ. J Neurosci. 1998;18:8133-8144.

35. Farhang B, Pietruszewski L, Lutfy K, Wagner EJ. The role of the NOP receptor in regulating food intake, meal pattern, and the excitability of proopiomelanocortin neurons. Neuropharmacology. 2010;59:190-200.

36. Chee MJ, Price CJ, Statnick MA, Colmers WF. Nociceptin/orphanin FQ suppresses the excitability of neurons in the ventromedial nucleus of the hypothalamus. J Physiol. 2011;589(Pt 13):31033114 .

37. Borgquist A, Kachani M, Tavitian N, Sinchak K, Wagner EJ. Estradiol negatively modulates the pleiotropic actions of orphanin FQ/ nociceptin at proopiomelanocortin synapses. Neuroendocrinology. 2013;98:60-72.

38. Hernandez J, Fabelo C, Perez L, Moore C, Chang R, Wagner EJ. Nociceptin/orphanin FQ modulates energy homeostasis through inhibition of neurotransmission at VMN SF-1/ARC POMC synapses in a sex- and diet-dependent manner. Biol Sex Differ. 2019;10:9.

39. Xie X, Wisor JP, Hara J, Crowder TL, LeWinter R, Khroyan TV, Yamanaka A, Diano S, Horvath TL, Sakurai T, Toll L, Kilduff TS. Hypocretin/orexin and nociceptin/orphanin FQ coordinately regulate analgesia in a mouse model of stress-induced analgesia. $J$ Clin Invest. 2008;118:2471-2481. 
40. Meis S, Munsch T, Pape HC. Antioscillatory effects of nociceptin/ orphanin FQ in synaptic networks of the rat thalamus. J Neurosci. 2002;22:718-727.

41. Connor M, Yeo A, Henderson G. The effect of nociceptin on $\mathrm{Ca}^{2+}$ channel current and intracellular $\mathrm{Ca}^{2+}$ in the SH-SY5Y human neuroblastoma cell line. Br J Pharmacol. 1996;118:205-207.

42. Vaughan CW, Connor M, Jennings EA, Marinelli S, Allen RG, Christie MJ. Actions of nociceptin/orphanin FQ and other prepronociceptin products on rat rostral ventromedial medulla neurons in vitro. J Physiol. 2001;534(Pt 3):849-859.

43. Zamponi GW, Snutch TP. Decay of prepulse facilitation of $\mathrm{N}$ type calcium channels during $\mathrm{G}$ protein inhibition is consistent with binding of a single Gbeta subunit. Proc Natl Acad Sci U S A. 1998;95:4035-4039.

44. Pu L, Bao GB, Ma L, Pei G. Acute desensitization of nociceptin/orphanin FQ inhibition of voltage-gated calcium channels in freshly dissociated hippocampal neurons. Eur J Neurosci. 1999;11:36103616.

45. Connor M, Christie MJ. Modulation of $\mathrm{Ca}^{2+}$ channel currents of acutely dissociated rat periaqueductal grey neurons. J Physiol. 1998;509(Pt 1):47-58.

46. Borgland SL, Connor M, Christie MJ. Nociceptin inhibits calcium channel currents in a subpopulation of small nociceptive trigeminal ganglion neurons in mouse. J Physiol. 2001;536(Pt 1):35-47.

47. Altier C, Khosravani H, Evans RM, Hameed S, Peloquin JB, Vartian BA, Chen L, Beedle AM, Ferguson SS, Mezghrani A, Dubel SJ, Bourinet E, McRory JE, Zamponi GW. ORL1 receptor-mediated internalization of N-type calcium channels. Nat Neurosci. 2006;9:31-40.

48. Murali SS, Napier IA, Rycroft BK, Christie MJ. Opioid-related (ORL1) receptors are enriched in a subpopulation of sensory neurons and prolonged activation produces no functional loss of surface N-type calcium channels. J Physiol. 2012;590:1655-1667.

49. Spampinato S, Di Toro R, Qasem AR. Nociceptin-induced internalization of the ORL1 receptor in human neuroblastoma cells. Neuroreport. 2001;12:3159-3163.

50. Gavioli EC, Vaughan CW, Marzola G, Guerrini R, Mitchell VA, Zucchini S, De Lima TC, Rae GA, Salvadori S, Regoli D, Calo' G. Antidepressant-like effects of the nociceptin/orphanin FQ receptor antagonist UFP-101: new evidence from rats and mice. Naunyn Schmiedebergs Arch Pharmacol. 2004;369:547-553.

51. Kawahara Y, Hesselink MB, van Scharrenburg G, Westerink BH. Tonic inhibition by orphanin FQ/nociceptin of noradrenaline neurotransmission in the amygdala. Eur J Pharmacol. 2004;485:197200.

52. Yoshitake S, Ijiri S, Kehr J, Yoshitake T. Concurrent modulation of extracellular levels of noradrenaline and cAMP during stress and by anxiogenic- or anxiolytic-like neuropeptides in the prefrontal cortex of awake rats. Neurochem Int 2013;62:314-323.

53. Okawa H, Kudo M, Kudo T, Guerrini R, Lambert DG, Kushikata T, Yoshida $\mathrm{H}$, Matsuki A. Effects of nociceptinNH $\mathrm{H}_{2}$ and $\left[\mathrm{Nphe}^{1}\right.$ ] nociceptin(1-13) $\mathrm{NH}_{2}$ on rat brain noradrenaline release in vivo and in vitro. Neurosci Lett. 2001;303:173-176.

54. Siniscalchi A, Rodi D, Morari M, Marti M, Cavallini S, Marino S, Beani L, Bianchi C. Direct and indirect inhibition by nociceptin/ orphanin FQ on noradrenaline release from rodent cerebral cortex in vitro. Br J Pharmacol. 2002;136:1178-1184.
55. Rominger A1, Förster S, Zentner J, Dooley DJ, McKnight AT, Feuerstein TJ, Jackisch R, Vlaskovska M. Comparison of the ORL1 receptor-mediated inhibition of noradrenaline release in human and rat neocortical slices. Br J Pharmacol. 2002;135:800-806.

56. Marti M, Stocchi S, Paganini F, Mela F, De Risi C, Calo' G, Guerrini R, Barnes TA, Lambert DG, Beani L, Bianchi C, Morari M. Pharmacological profiles of presynaptic nociceptin/orphanin FQ receptors modulating 5-hydroxytryptamine and noradrenaline release in the rat neocortex. BrJ Pharmacol. 2003;138:91-98.

57. Schlicker E, Morari M. Nociceptin/orphanin FQ and neurotransmitter release in the central nervous system. Peptides. 2000;21:1023-1029.

58. Schlicker E, Werthwein S, Kathmann M, Bauer U. Nociceptin inhibits noradrenaline release in the mouse brain cortex via presynaptic ORL1 receptors. Naunyn Schmiedebergs Arch Pharmacol. 1998;358:418-422.

59. Florin S, Leroux-Nicollet I, Meunier JC, Costentin J. Autoradiographic localization of $\left[{ }^{3} \mathrm{H}\right]$ nociceptin binding sites from telencephalic to mesencephalic regions of the mouse brain. Neurosci Lett. 1997;230:33-36.

60. Norton CS, Neal CR, Kumar S, Akil H, Watson SJ. Nociceptin/orphanin FQ and opioid receptor-like receptor mRNA expression in dopamine systems. J Comp Neurol. 2002;444:358-368.

61. Maidment NT, Chen Y, Tan AM, Murphy NP, Leslie FM. Rat ventral midbrain dopamine neurons express the orphanin FQ/nociceptin receptor ORL-1. Neuroreport. 2002;13:1137-1140.

62. Olianas MC, Dedoni S, Boi M, Onali P. Activation of nociceptin/ orphanin FQ-NOP receptor system inhibits tyrosine hydroxylase phosphorylation, dopamine synthesis, and dopamine $\mathrm{D}_{1}$ receptor signaling in rat nucleus accumbens and dorsal striatum. J Neurochem. 2008;107:544-556.

63. Lutfy K, Do T, Maidment NT. Orphanin FQ/nociceptin attenuates motor stimulation and changes in nucleus accumbens extracellular dopamine induced by cocaine in rats. Psychopharmacology (Berl). 2001;154:1-7.

64. Murphy NP, Maidment NT. Orphanin FQ/nociceptin modulation of mesolimbic dopamine transmission determined by microdialysis. J Neurochem. 1999;73:179-186.

65. Koizumi M, Sakoori K, Midorikawa N, Murphy NP. The NOP (ORL1) receptor antagonist Compound B stimulates mesolimbic dopamine release and is rewarding in mice by a non-NOP-receptor-mediated mechanism. Br J Pharmacol. 2004;143:53-62.

66. Vazquez-DeRose J, Stauber G, Khroyan TV, Xie XS, Zaveri NT, Toll L. Retrodialysis of N/OFQ into the nucleus accumbens shell blocks cocaine-induced increases in extracellular dopamine and locomotor activity. Eur J Pharmacol. 2013;699:200-206.

67. Murphy NP, Tan AM, Lam HA, Maidment NT. Nociceptin/orphanin FQ modulation of rat midbrain dopamine neurons in primary culture. Neuroscience. 2004;127:929-940.

68. Zheng F, Grandy DK, Johnson SW. Actions of orphanin FQ/nociceptin on rat ventral tegmental area neurons in vitro. Br J Pharmacol. 2002;136:1065-1071.

69. Sesack SR, Pickel VM. Ultrastructural relationships between terminals immunoreactive for enkephalin, GABA, or both transmitters in the rat ventral tegmental area. Brain Res. 1995;672:261-275.

70. Kalivas PW, Churchill L, Klitenick MA. GABA and enkephalin projection from the nucleus accumbens and ventral pallidum to 
the ventral tegmental area. Neuroscience. 1993;57:1047-1060.

71. Sesack SR, Pickel VM. Dual ultrastructural localization of enkephalin and tyrosine hydroxylase immunoreactivity in the rat ventral tegmental area: multiple substrates for opiate-dopamine interactions. J Neurosci. 1992;12:1335-1350.

72. Starr MS. Multiple opiate receptors may be involved in suppressing gamma-aminobutyrate release in substantia nigra. Life Sci. 1985;37:2249-2255.

73. Tanaka E, North RA. Opioid actions on rat anterior cingulate cortex neurons in vitro. J Neurosci. 1994;14(3 Pt 1):1106-1113.

74. Mogil JS, Grisel JE, Zhangs G, Belknap JK, Grandy DK. Functional antagonism of mu-, delta- and kappa-opioid antinociception by orphanin FQ. Neurosci Lett. 1996;214:131-134.

75. Van Bockstaele EJ, Pickel VM. GABA-containing neurons in the ventral tegmental area project to the nucleus accumbens in rat brain. Brain Res. 1995;682:215-221.

76. Anton B, Fein J, To T, Li X, Silberstein L, Evans CJ. Immunohistochemical localization of ORL-1 in the central nervous system of the rat. J Comp Neurol. 1996;368:229-251.

77. Le Maître E, Vilpoux C, Costentin J, Leroux-Nicollet I. Opioid receptor-like 1 (NOP) receptors in the rat dorsal raphe nucleus: evidence for localization on serotoninergic neurons and functional adaptation after 5,7-dihydroxytryptamine lesion. J Neurosci Res. 2005;81:488-496.

78. Nazzaro C, Barbieri M, Varani K, Beani L, Valentino RJ, Siniscalchi A. Swim stress enhances nociceptin/orphanin FQ-induced inhibition of rat dorsal raphe nucleus activity in vivo and in vitro: role of corticotropin releasing factor. Neuropharmacology. 2010;58:457464.

79. Nazzaro C, Marino S, Barbieri M, Siniscalchi A. Inhibition of serotonin outflow by nociceptin/orphaninFQ in dorsal raphe nucleus slices from normal and stressed rats: role of corticotropin releasing factor. Neurochem Int. 2009;54:378-384.

80. Tao R, Ma Z, Thakkar MM, McCarley RW, Auerbach SB. Nociceptin/orphanin FQ decreases serotonin efflux in the rat brain but in contrast to a kappa-opioid has no antagonistic effect on muopioid-induced increases in serotonin efflux. Neuroscience. 2007; 147:106-116

81. Le Maître E, Dourmap N, Vilpoux C, Leborgne R, Janin F, Bonnet JJ, Costentin J, Leroux-Nicollet I. Acute and subchronic treatments with selective serotonin reuptake inhibitors increase Nociceptin/ Orphanin FQ (NOP) receptor density in the rat dorsal raphe nucleus; interactions between nociceptin/NOP system and serotonin. Brain Res. 2013;1520:51-60.

82. Sbrenna S, Marti M, Morari M, Calo' G, Guerrini R, Beani L, Bianchi C. Modulation of 5-hydroxytryptamine efflux from rat cortical synaptosomes by opioids and nociceptin. Br J Pharmacol. 2000;130:425-433.

83. Calo G, Rizzi A, Rizzi D, Bigoni R, Guerrini R, Marzola G, Marti M, McDonald J, Morari M, Lambert DG, Salvadori S, Regoli D. $\left[\mathrm{Nphe}^{1}, \mathrm{Arg}^{14}{ }^{\text {Lys }}{ }^{15}\right]$ nociceptin- $\mathrm{NH}_{2}$, a novel potent and selective antagonist of the nociceptin/orphanin FQ receptor. Br J Pharmacol. 2002;136:303-311.

84. Werthwein S, Bauer U, Nakazi M, Kathmann M, Schlicker E. Further characterization of the ORL1 receptor-mediated inhibition of noradrenaline release in the mouse brain in vitro. Br J Pharmacol. 1999;127:300-308
85. Berger B, Rothmaier AK, Wedekind F, Zentner J, Feuerstein TJ, Jackisch R. Presynaptic opioid receptors on noradrenergic and serotonergic neurons in the human as compared to the rat neocortex. Br J Pharmacol. 2006;148:795-806.

86. Devine DP, Watson SJ, Akil H. Nociceptin/orphanin FQ regulates neuroendocrine function of the limbic-hypothalamic-pituitaryadrenal axis. Neuroscience. 2001;102:541-553.

87. Leggett JD, Harbuz MS, Jessop DS, Fulford AJ. The nociceptin receptor antagonist $\left[\mathrm{Nphe}^{1}{ }^{1} \mathrm{Arg}^{14}\right.$, Lys $\left.^{15}\right]$ nociceptin/orphanin FQ- $\mathrm{NH}_{2}$ blocks the stimulatory effects of nociceptin/orphanin FQ on the HPA axis in rats. Neuroscience. 2006;141:2051-2057.

88. Nicholson JR, Akil H, Watson SJ. Orphanin FQ-induced hyperphagia is mediated by corticosterone and central glucocorticoid receptors. Neuroscience. 2002;115:637-643.

89. Le Cudennec C, Naudin B, Do Rego JC, Costentin J. Nociceptin/ orphanin FQ and related peptides reduce the increase in plasma corticosterone elicited in mice by an intracerebroventricular injection. Life Sci. 2002;72:163-171.

90. Fernandez F, Misilmeri MA, Felger JC, Devine DP. Nociceptin/orphanin FQ increases anxiety-related behavior and circulating levels of corticosterone during neophobic tests of anxiety. Neuropsychopharmacology. 2004;29:59-71.

91. Green MK, Barbieri EV, Brown BD, Chen KW, Devine DP. Roles of the bed nucleus of stria terminalis and of the amygdala in N/ OFQ-mediated anxiety and HPA axis activation. Neuropeptides. 2007;41:399-410.

92. Gottlieb HB, Fleming TM, Ji L, Cunningham JT. Identification of central nervous system sites involved in the water diuresis response elicited by central microinjection of nociceptin/Orphanin FQ in conscious rats via c-Fos and inducible cAMP early repressor immunocytochemistry. J Neuroendocrinol. 2007;19:531-542.

93. Kazi JA. Nocistatin and nociceptin modulate c-Fos expression in the mice thalamus. Neurol Sci. 2012;33:1233-1237.

94. Olszewski PK, Billington CJ, Levine AS. Fos expression in feedingrelated brain areas following intracerebroventricular administration of orphanin FQ in rats. Brain Res. 2000;855:171-175.

95. Leggett JD, Dawe KL, Jessop DS, Fulford AJ. Endogenous nociceptin/orphanin FQ system involvement in hypothalamicpituitary-adrenal axis responses: relevance to models of inflammation. J Neuroendocrinol. 2009;21:888-897.

96. Kawashima N, Fugate J, Kusnecov AW. Immunological challenge modulates brain orphanin FQ/nociceptin and nociceptive behavior. Brain Res. 2002;949:71-78.

97. Nativio P, Pascale E, Maffei A, Scaccianoce S, Passarelli F. Effect of stress on hippocampal nociceptin expression in the rat. Stress. 2012;15:378-384.

98. Delaney G, Dawe KL, Hogan R, Hunjan T, Roper J, Hazell G, Lolait SJ, Fulford AJ. Role of nociceptin/orphanin FQ and NOP receptors in the response to acute and repeated restraint stress in rats. J Neuroendocrinol. 2012;24:1527-1541.

99. Green MK, Devine DP. Nociceptin/orphanin FQ and NOP receptor gene regulation after acute or repeated social defeat stress. Neuropeptides. 2009;43:507-514.

100. Martinez M, Phillips PJ, Herbert J. Adaptation in patterns of c-fos expression in the brain associated with exposure to either single or repeated social stress in male rats. Eur J Neurosci. 1998;10:20-33.

101. Pan YX, Xu J, Pasternak GW. Structure and characterization of 
the gene encoding a mouse kappa3-related opioid receptor. Gene. 1996;171:255-260.

102. Xie GX, Ito E, Maruyama K, Suzuki Y, Sugano S, Sharma M, Pietruck C, Palmer PP. The promoter region of human prepronociceptin gene and its regulation by cyclic AMP and steroid hormones. Gene. 1999;238:427-436.

103. Granholm L, Roman E, Nylander I. Single housing during early adolescence causes time-, area- and peptide-specific alterations in endogenous opioids of rat brain. Br J Pharmacol. 2015;172:606-614.

104. Tolchard S, Hare AS, Nutt DJ, Clarke G. TNF alpha mimics the endocrine but not the thermoregulatory responses of bacterial lipopolysaccharide (LPS): correlation with FOS-expression in the brain. Neuropharmacology. 1996;35:243-248.

105. Devine DP, Hoversten MT, Ueda Y, Akil H. Nociceptin/orphanin FQ content is decreased in forebrain neurones during acute stress. $J$ Neuroendocrinol. 2003;15:69-74.

106. Ploj K, Roman E, Nylander I. Effects of maternal separation on brain nociceptin/orphanin FQ peptide levels in male Wistar rats. Pharmacol Biochem Behav. 2002;73:123-129.

107. Reiss D, Wolter-Sutter A, Krezel W, Ouagazzal AM. Effects of social crowding on emotionality and expression of hippocampal nociceptin/orphanin FQ system transcripts in mice. Behav Brain Res. 2007;184:167-173.

108. Alder J, Kallman S, Palmieri A, Khadim F, Ayer JJ, Kumar S, Tsung K, Grinberg I, Thakker-Varia S. Neuropeptide orphanin FQ inhibits dendritic morphogenesis through activation of RhoA. Dev Neurobiol. 2013;73:769-784.

109. Ring RH, Alder J, Fennell M, Kouranova E, Black IB, ThakkerVaria S. Transcriptional profiling of brain-derived-neurotrophic factor-induced neuronal plasticity: a novel role for nociceptin in hippocampal neurite outgrowth. J Neurobiol. 2006;66:361-377.

110. Gavioli EC, Marzola G, Guerrini R, Bertorelli R, Zucchini S, De Lima TC, Rae GA, Salvadori S, Regoli D, Calo G. Blockade of nociceptin/orphanin FQ-NOP receptor signalling produces antidepressant-like effects: pharmacological and genetic evidences from the mouse forced swimming test. Eur J Neurosci. 2003;17:1987-1990.

111. Redrobe JP, Calo' G, Regoli D, Quirion R. Nociceptin receptor antagonists display antidepressant-like properties in the mouse forced swimming test. Naunyn Schmiedebergs Arch Pharmacol. 2002;365:164-167.

112. Holanda VAD, Santos WB, Asth L, Guerrini R, Calo' G, Ruzza C, Gavioli EC. NOP agonists prevent the antidepressant-like effects of nortriptyline and fluoxetine but not R-ketamine. Psychopharmacology (Berl). 2018;235:3093-3102.

113. Rizzi A, Gavioli EC, Marzola G, Spagnolo B, Zucchini S, Ciccocioppo R, Trapella C, Regoli D, Calò G. Pharmacological characterization of the nociceptin/orphanin FQ receptor antagonist SB612111 [(-)-cis-1-methyl-7-[[4-(2,6-dichlorophenyl)piperidin-1-yl] methyl]-6,7,8,9-tetrahydro-5H-benzocyclohepten-5-ol]: in vivo studies. J Pharmacol Exp Ther. 2007;321:968-974.

114. Holanda VA, Medeiros IU, Asth L, Guerrini R, Calo' G, Gavioli EC. Antidepressant activity of nociceptin/orphanin FQ receptor antagonists in the mouse learned helplessness. Psychopharmacology (Berl). 2016;233:2525-2532.

115. Medeiros IU, Ruzza C, Asth L, Guerrini R, Romão PR, Gavioli EC, Calo G. Blockade of nociceptin/orphanin FQ receptor signaling reverses LPS-induced depressive-like behavior in mice. Peptides.
2015;72:95-103.

116. Vitale G, Filaferro M, Micioni Di Bonaventura MV, Ruggieri V, Cifani C, Guerrini R, Simonato M, Zucchini S. Effects of [Nphe',

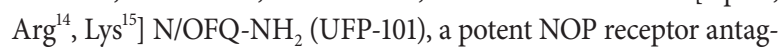
onist, on molecular, cellular and behavioural alterations associated with chronic mild stress. J Psychopharmacol. 2017;31:691-703.

117. Vitale G, Ruggieri V, Filaferro M, Frigeri C, Alboni S, Tascedda F, Brunello N, Guerrini R, Cifani C, Massi M. Chronic treatment with the selective NOP receptor antagonist $\left[\mathrm{Nphe}^{1}, \mathrm{Arg}^{14}, \mathrm{Lys}^{15}\right] \mathrm{N} / \mathrm{OFQ}-$ $\mathrm{NH}_{2}$ (UFP-101) reverses the behavioural and biochemical effects of unpredictable chronic mild stress in rats. Psychopharmacology (Berl). 2009;207:173-189.

118. Gu H, Hu D, Hong XR, Mao J, Cui Y, Hui N, Sha JY. Changes and significance of orphanin and serotonin in patients with postpartum depression. Zhonghua Fu Chan Ke Za Zhi. 2003;38:727-728.

119. Wang LN, Liu LF, Zhang JX, Zhao GF. Plasma levels of nociceptin/ orphanin FQ in patients with bipolar disorders and health adults. Zhonghua Yi Xue Za Zhi. 2009;89:916-918.

120. Aziz AM, Brothers S, Sartor G, Holm L, Heilig M, Wahlestedt C, Thorsell A. The nociceptin/orphanin FQ receptor agonist SR-8993 as a candidate therapeutic for alcohol use disorders: validation in rat models. Psychopharmacology (Berl). 2016;233:3553-3563.

121. aan het Rot M, Mathew SJ, Charney DS. Neurobiological mechanisms in major depressive disorder. CMAJ. 2009;180:305-313.

122. Nestler EJ, Barrot M, DiLeone RJ, Eisch AJ, Gold SJ, Monteggia LM. Neurobiology of depression. Neuron. 2002;34:13-25.

123. Detke MJ, Rickels M, Lucki I. Active behaviors in the rat forced swimming test differentially produced by serotonergic and noradrenergic antidepressants. Psychopharmacology (Berl). 1995;121:6672.

124. Hughes ZA, Stanford SC. A partial noradrenergic lesion induced by DSP-4 increases extracellular noradrenaline concentration in rat frontal cortex: a microdialysis study in vivo. Psychopharmacology (Berl). 1998;136:299-303.

125. Cryan JF, Page ME, Lucki I. Noradrenergic lesions differentially alter the antidepressant-like effects of reboxetine in a modified forced swim test. Eur J Pharmacol. 2002;436:197-205.

126. Kirby LG, Allen AR, Lucki I. Regional differences in the effects of forced swimming on extracellular levels of 5-hydroxytryptamine and 5-hydroxyindoleacetic acid. Brain Res. 1995;682:189-196.

127. Mangiavacchi S, Masi F, Scheggi S, Leggio B, De Montis MG, Gambarana C. Long-term behavioral and neurochemical effects of chronic stress exposure in rats. J Neurochem. 2001;79:1113-1121.

128. Ressler KJ, Nemeroff CB. Role of serotonergic and noradrenergic systems in the pathophysiology of depression and anxiety disorders. Depress Anxiety. 2000;12 Suppl 1:2-19.

129. Rosa-Neto P, Diksic M, Okazawa H, Leyton M, Ghadirian N, Mzengeza S, Nakai A, Debonnel G, Blier P, Benkelfat C. Measurement of brain regional alpha-[11C]methyl-L-tryptophan trapping as a measure of serotonin synthesis in medication-free patients with major depression. Arch Gen Psychiatry. 2004;61:556-563.

130. Arnone D, McIntosh AM, Ebmeier KP, Munafò MR, Anderson IM. Magnetic resonance imaging studies in unipolar depression: systematic review and meta-regression analyses. Eur Neuropsychopharmacol. 2012;22:1-16.

131. Cole J, Costafreda SG, McGuffin P, Fu CH. Hippocampal atrophy in first episode depression: a meta-analysis of magnetic resonance 
imaging studies. J Affect Disord. 2011;134:483-487.

132. Zhang FF, Peng W, Sweeney JA, Jia ZY, Gong QY. Brain structure alterations in depression: Psychoradiological evidence. CNS Neurosci Ther. 2018;24:994-1003.

133. Kang HJ, Voleti B, Hajszan T, Rajkowska G, Stockmeier CA, Licznerski $\mathrm{P}$, et al. Decreased expression of synapse-related genes and loss of synapses in major depressive disorder. Nat Med. 2012;18:1413-1417.

134. Rajkowska G, Miguel-Hidalgo JJ, Wei J, Dilley G, Pittman SD, Meltzer HY, Overholser JC, Roth BL, Stockmeier CA. Morphometric evidence for neuronal and glial prefrontal cell pathology in major depression. Biol Psychiatry. 1999;45:1085-1098.

135. Stockmeier CA, Mahajan GJ, Konick LC, Overholser JC, Jurjus GJ, Meltzer HY, et al. Cellular changes in the postmortem hippocampus in major depression. Biol Psychiatry. 2004;56:640-650.

136. Sheline YI, Gado MH, Kraemer HC. Untreated depression and hippocampal volume loss. Am J Psychiatry. 2003;160:1516-1518.

137. Duman RS, Aghajanian GK. Synaptic dysfunction in depression: potential therapeutic targets. Science. 2012;338:68-72.

138. McEwen BS, Nasca C, Gray JD. Stress effects on neuronal structure: hippocampus, amygdala, and prefrontal cortex. Neuropsychopharmacol. 2016;41:3-23.

139. Castrén E, Kojima M. Brain-derived neurotrophic factor in mood disorders and antidepressant treatments. Neurobiol Dis. 2017;97(Pt B):119-126.

140. Levy MJF, Boulle F, Steinbusch HW, van den Hove DLA, Kenis G, Lanfumey L. Neurotrophic factors and neuroplasticity pathways in the pathophysiology and treatment of depression. Psychopharmacol (Berl). 2018;235:2195-2220.

141. Dunham JS, Deakin JFW, Miyajima F, Payton A, Toro CT. Expression of hippocampal brain-derived neurotrophic factor and its receptors in Stanley consortium brains. J Psychiatr Res. 2009;43:11751184.

142. Pandey GN, Ren X, Rizavi HS, Conley RR, Roberts RC, Dwivedi Y. Brain-derived neurotrophic factor and tyrosine kinase $\mathrm{B}$ receptor signalling in post-mortem brain of teenage suicide victims. Int $J$ Neuropsychopharmacol. 2008;11:1047-1061.

143. Gaughran F, Payne J, Sedgwick PM, Cotter D, Berry M. Hippocampal FGF-2 and FGFR1 mRNA expression in major depression, schizophrenia and bipolar disorder. Brain Res Bull. 2006;70:221227.

144. Chen B, Dowlatshahi D, MacQueen GM, Wang JF, Young LT. Increased hippocampal BDNF immunoreactivity in subjects treated with antidepressant medication. Biol Psychiatry. 2001;50:260-265.

145. Evans SJ, Choudary PV, Neal CR, Li JZ, Vawter MP, Tomita H, Lopez JF, Thompson RC, Meng F, Stead JD, Walsh DM, Myers RM, Bunney WE, Watson SJ, Jones EG, Akil H. Dysregulation of the fibroblast growth factor system in major depression. Proc Natl Acad Sci U S A. 2004;101:15506-15511.

146. Deng Z, Deng S, Zhang MR, Tang MM. Fibroblast growth factors in depression. Front Pharmacol. 2019;10:60.

147. Elsayed M, Banasr M, Duric V, Fournier NM, Licznerski P, Duman RS. Antidepressant effects of fibroblast growth factor-2 in behavioral and cellular models of depression. Biol Psychiatry. 2012;72:258-265.

148. Shirayama Y, Chen AC, Nakagawa S, Russell DS, Duman RS. Brain-derived neurotrophic factor produces antidepressant effects in behavioral models of depression. J Neurosci. 2002;22:3251-3261.

149. Turner CA, Gula EL, Taylor LP, Watson SJ, Akil H. Antidepressantlike effects of intracerebroventricular FGF2 in rats. Brain Res. 2008;1224:63-68.

150. Bachis A, Mallei A, Cruz MI, Wellstein A, Mocchetti I. Chronic antidepressant treatments increase basic fibroblast growth factor and fibroblast growth factor-binding protein in neurons. Neuropharmacol. 2008;55:1114-1120.

151. Mallei A, Shi B, Mocchetti I. Antidepressant treatments induce the expression of basic fibroblast growth factor in cortical and hippocampal neurons. Mol Pharmacol. 2002;61:1017-1024.

152. Nibuya M, Morinobu S, Duman RS. Regulation of BDNF and trkB mRNA in rat brain by chronic electroconvulsive seizure and antidepressant drug treatments. J Neurosci. 1995;15:7539-7547.

153. Zhang Y, Gu F, Chen J, Dong W. Chronic antidepressant administration alleviates frontal and hippocampal BDNF deficits in CUMS rat. Brain Res. 2010;1366:141-148.

154. Monteggia LM, Barrot M, Powell CM, Berton O, Galanis V, Gemelli T, Meuth S, Nagy A, Greene RW, Nestler EJ. Essential role of brain-derived neurotrophic factor in adult hippocampal function. Proc Natl Acad Sci U S A. 2004;101:10827-10832.

155. Saarelainen T, Hendolin P, Lucas G, Koponen E, Sairanen M, MacDonald E, Agerman K, Haapasalo A, Nawa H, Aloyz R, Ernfors P, Castrén E. Activation of the TrkB neurotrophin receptor is induced by antidepressant drugs and is required for antidepressant-induced behavioral effects. J Neurosci. 2003;23:349-357.

156. Simard S, Shail P, MacGregor J, El Sayed M, Duman RS, Vaccarino FM, Salmaso N. Fibroblast growth factor 2 is necessary for the antidepressant effects of fluoxetine. PLoS One. 2018;13:e204980.

157. Pariante CM. Risk factors for development of depression and psychosis. glucocorticoid receptors and pituitary implications for treatment with antidepressant and glucocorticoids. Ann N Y Acad Sci. 2009;1179:144-152.

158. Kvarta MD, Bradbrook KE, Dantrassy HM, Bailey AM, Thompson SM. Corticosterone mediates the synaptic and behavioral effects of chronic stress at rat hippocampal temporoammonic synapses. $J$ Neurophysiol. 2015;114:1713-1724.

159. Gourley SL, Taylor JR. Recapitulation and reversal of a persistent depression-like syndrome in rodents. Curr Protoc Neurosci. 2009; Chapter 9:Unit 9.32.

160. Gourley SL, Wu FJ, Kiraly DD, Ploski JE, Kedves AT, Duman RS, Taylor JR. Regionally specific regulation of ERK MAP kinase in a model of antidepressant-sensitive chronic depression. Biol Psychiatry. 2008;63:353-359.

161. Johnson SA, Fournier NM, Kalynchuk LE. Effect of different doses of corticosterone on depression-like behavior and HPA axis responses to a novel stressor. Behav Brain Res. 2006;168:280-288.

162. Wulsin AC, Herman JP, Solomon MB. Mifepristone decreases depression-like behavior and modulates neuroendocrine and central hypothalamic-pituitary-adrenocortical axis responsiveness to stress. Psychoneuroendocrinology. 2010;35:1100-1112.

163. Solomon MB, Wulsin AC, Rice T, Wick D, Myers B, McKlveen J, Flak JN, Ulrich-Lai Y, Herman JP. The selective glucocorticoid receptor antagonist CORT 108297 decreases neuroendocrine stress responses and immobility in the forced swim test. Horm Behav. 2014;65:363-371.

164. Wu LM, Han H, Wang QN, Hou HL, Tong H, Yan XB, Zhou JN. 
Mifepristone repairs region-dependent alteration of synapsin I in hippocampus in rat model of depression. Neuropsychopharmacol. 2007;32:2500-2510.

165. Block TS, Kushner H, Kalin N, Nelson C, Belanoff J, Schatzberg A. Combined analysis of mifepristone for psychotic depression: plasma levels associated with clinical response. Biol Psychiatry. 2018;84:46-54.

166. Lucassen PJ, Oomen CA, Naninck EF, Fitzsimons CP, van Dam AM, Czeh B, Korosi A. Regulation of adult neurogenesis and plasticity by (early) stress, glucocorticoids, and inflammation. Cold
Spring Harb Perspect Biol. 2015;7:a021303.

167. Oomen CA, Mayer JL, de Kloet ER, Joëls M, Lucassen PJ. Brief treatment with the glucocorticoid receptor antagonist mifepristone normalizes the reduction in neurogenesis after chronic stress. Eur J Neurosci. 2007;26:3395-3401.

168. Mayer JL, Klumpers L, Maslam S, de Kloet ER, Joëls M, Lucassen PJ. Brief treatment with the glucocorticoid receptor antagonist mifepristone normalises the corticosterone-induced reduction of adult hippocampal neurogenesis. J Neuroendocrinol. 2006;18:629631. 